\title{
EFFECT OF TEMPERATURE ON SHEAR STRENGTH AND YIELDING BEHAVIOR OF SOFT BANGKOK CLAY
}

\author{
Hossam M. Abuel-Naga ${ }^{\text {i) }}$, Dennes T. Bergado ${ }^{\text {ii) }}$ and Bee Fong Lim ${ }^{\text {iii) }}$
}

\begin{abstract}
This paper presents the results of an intensive laboratory study carried out on undisturbed soft Bangkok clay specimens to investigate the effect of temperature on shear strength and yielding behavior especially in states wetter than critical condition. Modified triaxial apparatus that can handle elevated temperature up to $100^{\circ} \mathrm{C}$ has been used in this study. The experimental program includes series of drained and undrained compression triaxial tests, and isotropic and anisotropic consolidation tests conducted at different temperature levels $\left(25,70,90^{\circ} \mathrm{C}\right)$. The results of the experimental program were analyzed in light of the definitions of the critical state soil mechanics theory. The outcomes of this study provide useful test results and thorough understanding that can enhance the constitutive modeling of saturated fine grained soils behavior under elevated temperatures.
\end{abstract}

Key words: Bangkok clay, flow rule, heat, shear strength, temperature effect, yielding (IGC: D8)

\section{INTRODUCTION}

The first experimental study on the effect of temperature on consolidation behavior of soils was reported by Gray (1936). During the last two decades, many researchers evaluated the thermo-hydro-mechanical (T-M-C) behavior of saturated fine grained soils under elevated temperatures, up to $100^{\circ} \mathrm{C}$, due to the need for safe design of (i) oil and gas pipelines (Slegel and Davis, 1977), (ii) buried high voltage electrical cables (Abdel-Hadi and Mitchell, 1981), (iii) ground heat energy storage (Moritz, 1995) and (iv) to evaluate the hydro-thermal performance of the nuclear waste disposal clay barriers (Gera et al., 1996). These studies have conclusively demonstrated that increasing the temperature of saturated fine-grained soils to less than the boiling point of water $\left(100^{\circ} \mathrm{C}\right)$ affects its engineering behavior (permeability, compressibility and shear strength). A comprehensive review of these aspects has been carried out by Laloui (2001).

The validity and efficiency of an innovative thermal technique capable of enhancing the performance of prefabricated vertical drains in soft Bangkok clay has been investigated recently with the view of improving its strength and hydraulics properties (Abuel-Naga et al., 2006a). For this purpose, a clear understanding of the temperature effects on the thermo-mechanical behaviour of the soft clay is required. Moreover, understanding the effect of temperature on the yielding and flow rule behavior is crucial for modeling purposes. The aim of this study is to investigate experimentally the effect of temperature up to $90^{\circ} \mathrm{C}$ on the shear strength and yielding behavior of soft Bangkok clay especially in states wetter than critical condition. Most of previous studies in literature have been directed to investigate only the effect of temperature on the shear strength of soils (e.g., Kuntiwattanakul et al., 1995; Burghignoli et al., 2000). However, very few studies have been directed to study the effect of temperature on the yielding and flow rule behavior (e.g., Graham et al., 2001; Cekerevac and Laloui, 2004).

The experimental program consists of compression triaxial drained and undrained shear test and anisotropic consolidation test at different constant stress ratios was designed so as to evaluate the following aspects of soft Bangkok clay under thermal loading: undrained and drained shear strength, stress-strain secant modulus, critical state line in the deviatoric and the volumetric plane, geometry of Roscoe surface, size of the elastic domain, compressibility index, and flow rule. A triaxial test apparatus which can handle temperature up to $100^{\circ} \mathrm{C}$ have been used in this study. The test results will be discussed in the light of the definitions of the soil mechanics critical state theory. Test specimen, testing equipment, and experimental program are described in detail in the following sections. Subsequently, the test results are presented and discussed. Then, conclusions are drawn.

i) Research Fellow, Department of Civil Engineering, Monash University, Australia (hossam.abuel-naga@eng.monash.edu.au).

ii) Professor of Geotechnical and Geoenvironmental Engineering, School of Engineering and Technology, Asian Institute of Technology, Thailand.

iii) M. Eng. Graduate, ditto.

The manuscript for this paper was received for review on November 9, 2005; approved on January $15,2007$.

Written discussions on this paper should be submitted before January 1, 2008 to the Japanese Geotechnical Society, 4-38-2, Sengoku, Bunkyo-ku, Tokyo 112-0011, Japan. Upon request the closing date may be extended one month. 
Table 1. Physical and chemical properties of soft Bangkok Clay

\begin{tabular}{|c|c|c|}
\hline \multirow{14}{*}{ 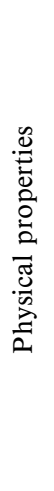 } & Liquid limit (\%) & 103 \\
\hline & Plasticity index & 60 \\
\hline & Water content (\%) & $90-95$ \\
\hline & Liquidity index & 0.83 \\
\hline & Specific gravity & 2.67 \\
\hline & Unit weight $\left(\mathrm{kN} / \mathrm{m}^{3}\right)$ & 14.9 \\
\hline & Void ratio & 2.4 \\
\hline & Color & Dark gray \\
\hline & Permeability & $\approx 5 \mathrm{E}-9$ \\
\hline & Specific surface area $\left(\mathrm{m}^{2} / \mathrm{g}\right)^{*}$ & 237 \\
\hline & Grain size distribution & \\
\hline & Clay (\%) & 78 \\
\hline & Silt (\%) & 22 \\
\hline & Sand (\%) & 0 \\
\hline \multirow{7}{*}{ 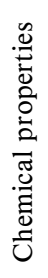 } & Cation exchange capacity & 20 \\
\hline & Exchangeable cations & \\
\hline & $\mathrm{Na}(\mathrm{meq} / 100 \mathrm{~g})$ & 1.44 \\
\hline & $\mathrm{K}(\mathrm{meq} / 100 \mathrm{~g})$ & 0.39 \\
\hline & $\mathrm{Mg}(\mathrm{meq} / 100 \mathrm{~g})$ & 10.29 \\
\hline & $\mathrm{Ca}(\mathrm{meq} / 100 \mathrm{~g})$ & 4.99 \\
\hline & $\mathrm{pH}$ & 7.3 \\
\hline
\end{tabular}

*Estimated using the empirical relationship of Chapuis and Aubertin (2003)

\section{TEST SPECIMEN}

The natural soft clay used in this study was extracted from a depth of 3.00 to $4.00 \mathrm{~m}$ of the soft clay layer in the campus of Asian Institute of Technology (AIT) which is within the Central Plain of Thailand. The Central Plain of Thailand is deposited with a deltaic-marine soft clay layer widely known as soft Bangkok clay. Table 1 shows the properties of soft Bangkok clay. The mineralogical composition of Bangkok clay was investigated by Ohtsubo et al. (2000) using XRD tests. The results show that Bangkok clay possessed Smectite, Kaolinite and Mica. The major clay mineral is a group of smectite (Montmorillonite and Illite) ranging from 54 to $71 \%$, followed by Kaolinite (28 to $36 \%$ ) and Mica.

\section{TEST APPARATUS}

The schematic diagram of the modified triaxial system used in this study is shown in Fig. 1. It comprises of a metallic triaxial cell with two transparent windows that can accommodate soil specimens up to $50 \mathrm{~mm}$ in diameter and $100 \mathrm{~mm}$ in height. Three ring heaters were placed on the outer wall of the cell and the required temperature was controlled by a K-type thermocouple placed inside the triaxial cell. The precision of the thermo-controller system is $\pm 0.1^{\circ} \mathrm{C}$. A burette with a least count of $0.01 \mathrm{ml}$ has been used for volume change measurements. A thermal cutoff unit $\left(25^{\circ} \mathrm{C}\right)$ has been used to minimize the effect of the thermal expansion of the connecting tubes. Similar technique has been used before by Sultan et al. (2002) and Cekerevac et al. (2005). Load cell and pore water pressure transducer that withstand elevated temperature up to $100^{\circ} \mathrm{C}$ were utilized in this study. A layer of oil $(5 \mathrm{~mm})$ was inserted to float

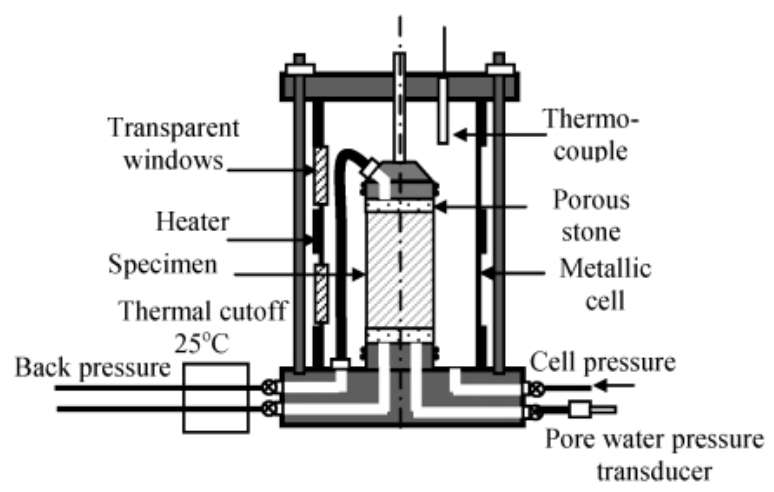

Fig. 1. Schematic diagram of the modified triaxial apparatus

on top of the water in the triaxial cell in order to lubricate triaxial piston (Head, 1986).

\section{Calibration of Temperature Effects on Volume Change Measurements}

In standard isothermal triaxial tests on saturated specimens of soils, volume changes are measured directly by monitoring the exchange of pore water through the back pressure line. However, this method is no longer valid in non-isothermal conditions, because of the thermal dilation of drainage system (porous stones, drainage lines, and the water filling both of them), and thermal dilation of soil specimen (water and solids). Therefore, under non-isothermal test condition, two types of corrections must be included, namely: thermal dilatation of drainage system and thermal dilatation of soil constituents.

In order to evaluate the effect of drainage system thermal dilatation, a calibration test, using two porous discs with filter paper and a steel dummy sample with strip filter papers, has been conducted. The drainage lines were filled with distilled de-aired water then the saturated porous discs and filter papers, dummy sample, and impermeable top cap were put in the bottom base of the triaxial cell. Then, the dummy sample was isolated by rubber membrane and sealed off with a pair of O-rings on each side. Thereafter, the cell was filled with distilled de-aired water. The cell pressure and back pressure were adjusted at 400 and $200 \mathrm{kPa}$ respectively. The value of $200 \mathrm{kPa}$ for back pressure was chosen since it is the value of the back pressure that used for all specimens in this study. The test began at room temperature followed by increasing the temperature by steps of $10^{\circ} \mathrm{C}$ up to $90^{\circ} \mathrm{C}$. Thereafter, temperature was decreased to $25^{\circ} \mathrm{C}$. During the heating/cooling cycle, the drainage system was open and the volume change was measured, when it stabilizes, at different temperature levels. Three heating/cooling cycles were conducted. Figure 2 shows the average volume change due to the dilatation of drainage system based on the three heating/cooling cycles test. The results indicated that the total volume changes during heating and cooling are approximately equal which can be considered as indicator for the zero leakage condition of the utilized apparatus. The observed volume change 


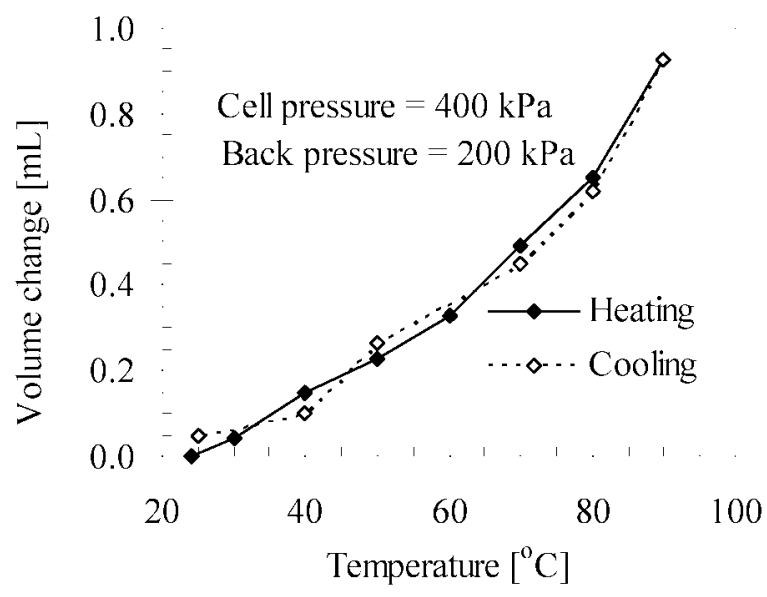

Fig. 2. Volume change of the triaxial apparatus drainage system under heating cooling cycle up to $90^{\circ} \mathrm{C}$

measurements during non-isothermal test conducted on soil specimen were corrected according to the calibration results shown in Fig. 2.

In order to include the effect of soil thermal dilatation, the volume change calculation was done based on the suggested procedure by Campanella and Mitchell (1968) and then improved by Delage et al. (2000). According to this concept, the volumetric strain $\varepsilon_{\mathrm{v}}$ of a soil during drained heating can be obtained by subtracting the volume due to the thermal expansion of water and solids from the total drained volume of water, $\Delta V_{\mathrm{dr}}$, giving:

$$
\varepsilon_{\mathrm{v}}=\frac{\left[\Delta V_{\mathrm{dr}}-\left(\alpha_{\mathrm{w}} V_{\mathrm{w}}+\alpha_{\mathrm{s}} V_{\mathrm{s}}\right) \Delta T\right]}{V}
$$

where $\alpha_{\mathrm{w}}$ and $V_{\mathrm{w}}$ are the thermal expansion coefficient and volume of water, respectively; $\alpha_{\mathrm{s}}$ and $V_{\mathrm{s}}$ are the thermal expansion coefficient and volume of the solid skeleton, respectively; and $V$ is the volume of the sample. The thermal expansion coefficient of solid was assumed as $\alpha_{\mathrm{s}}=3.5 \mathrm{E}-5^{\circ} \mathrm{C}^{-1}$ according to Campanella and Mitchell (1968).

\section{EXPERIMENTAL PROGRAM}

The experimental program consists of two types of tests using the modified triaxial test apparatus, namely: compression triaxial test and anisotropic consolidation test. The basic stress-strain definitions and the heating approach used in this study are presented in the following sections. The details of the experimental program and the testing procedures of different experiments are also described.

\section{Basic Stress-Strain Definitions}

The stress parameter $p$ and $q$ are defined by:

$$
\begin{gathered}
p=\frac{1}{3}\left(\sigma_{1}^{\prime}+\sigma_{2}^{\prime}+\sigma_{3}^{\prime}\right) \\
q=\sigma_{1}^{\prime}-\sigma_{3}^{\prime}
\end{gathered}
$$

in which $\sigma_{1}^{\prime}, \sigma_{2}^{\prime}$, and $\sigma_{3}^{\prime}$ are the principle effective compressive stress; $\sigma_{2}^{\prime}=\sigma_{3}^{\prime}$ under the triaxial stress system; and $p$ and $q$ are referred to as the mean normal stress and deviatoric stress, respectively. The stress ratio, $q / p$, is denoted by $\eta$.

The stress parameter, $p_{\mathrm{e}}$, is called the mean equivalent pressure and is defined as:

$$
p_{\mathrm{e}}=p_{\text {co }} \exp \left[\frac{e_{\mathrm{o}}-e}{\lambda}\right]
$$

where $p_{\text {co }}$ and $e_{\mathrm{o}}$ correspond to the consolidation pressure and voids ratio on the isotropic consolidation line $(\eta=$ 0.0 ); and $\eta$ is the slope of the isotropic consolidation line in $e-\ln (p)$ plot.

The incremental volumetric and shear strain $d \varepsilon_{\mathrm{v}}$ and $d \varepsilon_{\mathrm{s}}$, respectively, are determined as follows:

$$
\begin{gathered}
d \varepsilon_{\mathrm{v}}=d \varepsilon_{1}+d \varepsilon_{2}+d \varepsilon_{3} \\
d \varepsilon_{\mathrm{s}}=\frac{2}{3}\left(d \varepsilon_{1}-d \varepsilon_{3}\right)
\end{gathered}
$$

where $d \varepsilon_{1}, d \varepsilon_{2}$, and $d \varepsilon_{3}$ are the principal incremental compressive strains. For special case of axisymmetrical compression where $d \varepsilon_{2}=d \varepsilon_{3}$ (triaxial condition), the incremental shear strain $d \varepsilon_{\mathrm{s}}$ can be defined as follows:

$$
d \varepsilon_{\mathrm{s}}=d \varepsilon_{1}-\frac{d \varepsilon_{\mathrm{v}}}{3}
$$

where $\varepsilon_{1}$ and $\varepsilon_{\mathrm{v}}$ are the natural axial and the volumetric strain, respectively, that can be defined as follows:

$$
\begin{gathered}
\varepsilon_{1}=\ln \left(l_{\mathrm{o}} / l\right) \\
\varepsilon_{\mathrm{v}}=\ln \left(V_{\mathrm{o}} / V\right)
\end{gathered}
$$

where $l_{\mathrm{o}}$ and $V_{\mathrm{o}}$ are the initial height and volume of the specimen; $l$ and $V$ correspond to current values.

\section{Heating Approach}

Drained heating approach was adopted in this study. During the drained heating phase of different experiments, there should be no temperature induced excess pore pressure. This can be achieved by using any one of the two methods. The first method involves application of a very low heating rate under computer controlled zero pore pressure condition (Del Olmo et al., 1996). The second approach involves raising the temperature incrementally, when the volume change under the current temperature is stabilized (Towhata et al., 1993; Delage et al., 2000). The second approach has been adopted in this study. The incremental heating process of isotropic normally consolidated soft Bangkok clay is demonstrated in Fig. 3.

\section{Compression Triaxial Test Program}

The effect of temperature on the shear strength behavior has been evaluated experimentally at different temperature and stress levels. The term temperature history was used for specimens subjected to heating/cooling cycle before shearing. Table 2 includes the detailed experimental program of undrained and drained compression triaxial tests. Portion of undrained triaxial compression tests were conducted by Lim (2005). The height and the 


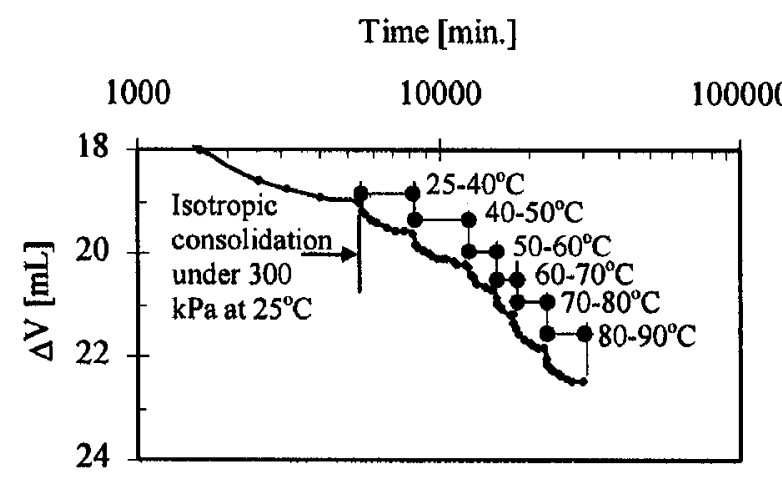

Fig. 3. Incremental temperature consolidation of isotropic normally consolidated specimen

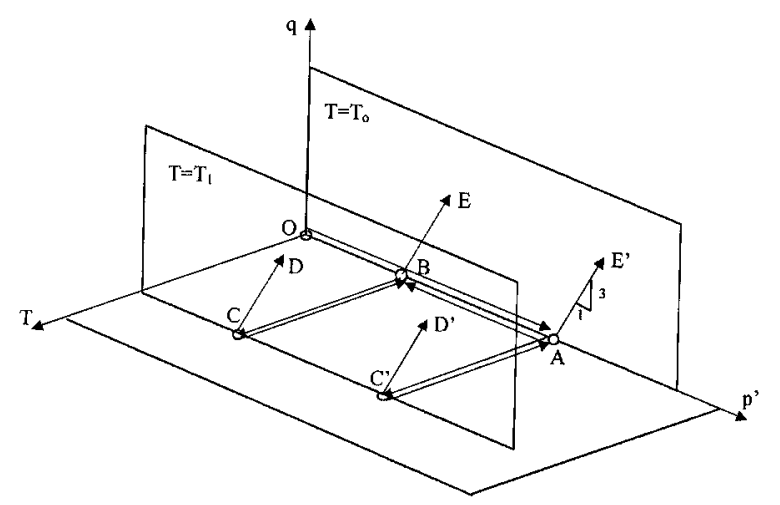

Fig. 4. Thermo-mechanical testing path of undrained and drained compression triaxial test

diameter of the tested specimen were 70 and $35 \mathrm{~mm}$, respectively. The thermo-mechanical testing path of standard undrained or drained compression triaxial tests is shown in Fig. 4 and the general testing procedures can be explained as follows:

1) Isotropic consolidation was imposed up to mean effective pressure of 200 or $300 \mathrm{kPa}$ (path $\mathrm{O}$ to $\mathrm{A}$ ), followed by an unloading in some cases (path A to B) resulting in different overconsolidation ratios $(\mathrm{OCR}$ $=1.0,1.5,2.0,4.0,8.0,9.0)$.

2) Incremental drained heating (path $A$ to $C^{\prime}$ or $B$ to $C$ ) was conducted for the specimen tested at elevated temperature. Drained heating/cooling cycle (path A to $\mathrm{C}^{\prime}$ to $\mathrm{A}$ or $\mathrm{B}$ to $\mathrm{C}$ to $\mathrm{B}$ ) was conducted for specimen tested after subjecting to temperature history.

3) Undrained or drained shearing (path $C$ to $D$ and $C^{\prime}$ to $\mathrm{D}^{\prime}$ at elevated temperature or, path $\mathrm{A}$ to $\mathrm{E}^{\prime}$ and $\mathrm{B}$ to $\mathrm{E}$ for either tests at ambient temperature or after subjecting to heating/cooling cycle) was performed by applying a standard triaxial compression shearing path $\Delta q / \Delta p=3.0$. Shear tests were carried out with strain rate of $2 \%$ per hour in undrained conditions and at $0.1 \%$ per hour in drained conditions. Readings of pore pressure response, axial deformation of the specimen, and axial load at selected intervals of time were recorded for undrained shearing test. Axial and volumetric deformations of the specimen, and axial load at selected intervals of time were recorded
Table 2. Experimental program of standard undrained and drained compression triaxial test $(\delta q / \delta p=3)$

\begin{tabular}{|c|c|c|c|c|}
\hline & $\begin{array}{c}\text { Sample } \\
\text { No. }\end{array}$ & $\begin{array}{c}P_{\mathrm{c}}^{\prime} \\
(\mathrm{kPa})\end{array}$ & OCR & $\begin{array}{l}\text { Pre-shearing } \\
\text { thermal loading } \\
\text { path }\left({ }^{\circ} \mathrm{C}\right)\end{array}$ \\
\hline \multirow{21}{*}{ 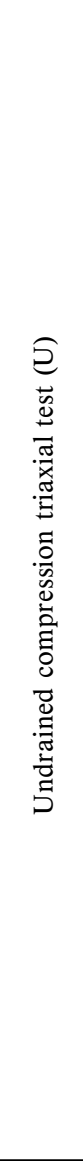 } & 1 & \multirow{9}{*}{200} & \multirow{3}{*}{1} & 25 \\
\hline & 2 & & & $25-70-25$ \\
\hline & 3 & & & $25-90-25$ \\
\hline & 4 & & \multirow{3}{*}{2} & 25 \\
\hline & 5 & & & $25-70-25$ \\
\hline & 6 & & & $25-90-25$ \\
\hline & 7 & & \multirow{3}{*}{4} & 25 \\
\hline & 8 & & & $25-70-25$ \\
\hline & 9 & & & $25-90-25$ \\
\hline & 10 & \multirow{2}{*}{200} & \multirow{2}{*}{1} & $25-70$ \\
\hline & 11 & & & $25-90$ \\
\hline & 12 & \multirow{7}{*}{300} & \multirow{3}{*}{1} & 25 \\
\hline & 13 & & & $25-70$ \\
\hline & 14 & & & $25-90$ \\
\hline & 15 & & \multirow{2}{*}{1.5} & 25 \\
\hline & 16 & & & $25-70$ \\
\hline & 17 & & \multirow{2}{*}{3} & 25 \\
\hline & 18 & & & $25-70$ \\
\hline & 19 & \multirow{3}{*}{400} & \multirow{3}{*}{1} & 25 \\
\hline & 20 & & & $25-70$ \\
\hline & 21 & & & $25-90$ \\
\hline \multirow{12}{*}{ 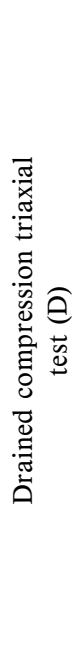 } & 22 & \multirow{12}{*}{300} & \multirow{3}{*}{1} & 25 \\
\hline & 23 & & & $25-70$ \\
\hline & 24 & & & $25-90$ \\
\hline & 25 & & \multirow{3}{*}{2} & 25 \\
\hline & 26 & & & $25-70$ \\
\hline & 27 & & & $25-90$ \\
\hline & 28 & & \multirow{3}{*}{4} & 25 \\
\hline & 29 & & & $25-70$ \\
\hline & 30 & & & $25-90$ \\
\hline & 31 & & \multirow{3}{*}{8} & 25 \\
\hline & 32 & & & $25-70$ \\
\hline & 33 & & & $25-90$ \\
\hline
\end{tabular}

$P_{\mathrm{c}}^{\prime}$ : preconsolidation pressure

for drained shearing test.

\section{Anisotropic Consolidation Test Program}

Anisotropic consolidation test was conducted at different constant stress ratios $(\eta=\delta q / \delta p=0.0,0.1,0.2$, $0.4,0.6,0.75$ ) and under different temperature levels $\left(25,70,90^{\circ} \mathrm{C}\right)$ using the modified triaxial apparatus. The height and the diameter of the tested specimen were 70 


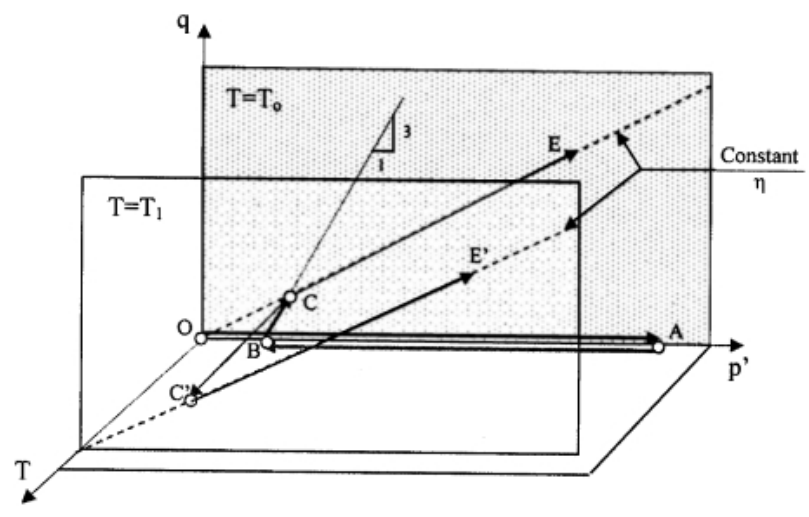

Fig. 5. Thermo-mechanical testing path of constant stress ratio test (anisotropic consolidation)

and $35 \mathrm{~mm}$, respectively. The test was conducted by increasing incrementally and simultaneously both cell pressure and hangers loads, which impose deviatoric stress, so that the required stress ratio was maintained constant (stress controlled technique). In order to keep the stress ratio $(\eta)$ constant, any increase in cell pressure $\left(d \sigma_{3}^{\prime}\right)$ was accompanied by a corresponding increase in the deviatoric stress $(d q)$ using the following formula:

$$
d q=\frac{3 \eta}{3-\eta} d \sigma_{3}^{\prime}
$$

The thermo-mechanical path of constant stress ratio test is shown in Fig. 5 and the general test procedures can be explained as follows:

1) Isotropic consolidation was imposed up to the mean effective pressure of $300 \mathrm{kPa}$ (path $\mathrm{O}$ to $\mathrm{A}$ ), followed by an unloading up to mean effective stress of $25 \mathrm{kPa}$ (path A to B) resulting in overconsolidation ratio of $\mathrm{OCR}=12$.

2) Drained shearing was done by increasing the deviatoric stress while the cell pressure was constant (standard triaxial shearing path $\Delta q / \Delta p=3.0$, path $\mathrm{B}$ to $\mathrm{C}$ ) until reaching the designated constant stress ratio $\eta$.

3) Incremental drained heating was performed in steps of $10^{\circ} \mathrm{C}$ (path $\mathrm{C}$ to $\mathrm{C}^{\prime}$ ).

4) Incremental and simultaneous increases of cell pressure and hanger load (deviatoric stress) are imposed according to Eq. 10 in order to maintain the designated stress ratio constant (path $\mathrm{C}$ to $\mathrm{E}$ at room temperature or path $\mathrm{C}^{\prime}$ to $\mathrm{E}^{\prime}$ at elevated temperature). The cell pressure increments were set to be $25 \mathrm{kPa}$. The volume change and axial displacement were recorded for each constant stress ratio increment. The next constant stress ratio increment was applied when the volume change reading of the current stress condition passes the primary consolidation stage.

\section{DISCUSSIONS OF TRIAXIAL COMPRESSION TEST RESULTS}

Thermal Induced Volumetric Strain

According to the test procedures, the soil specimens
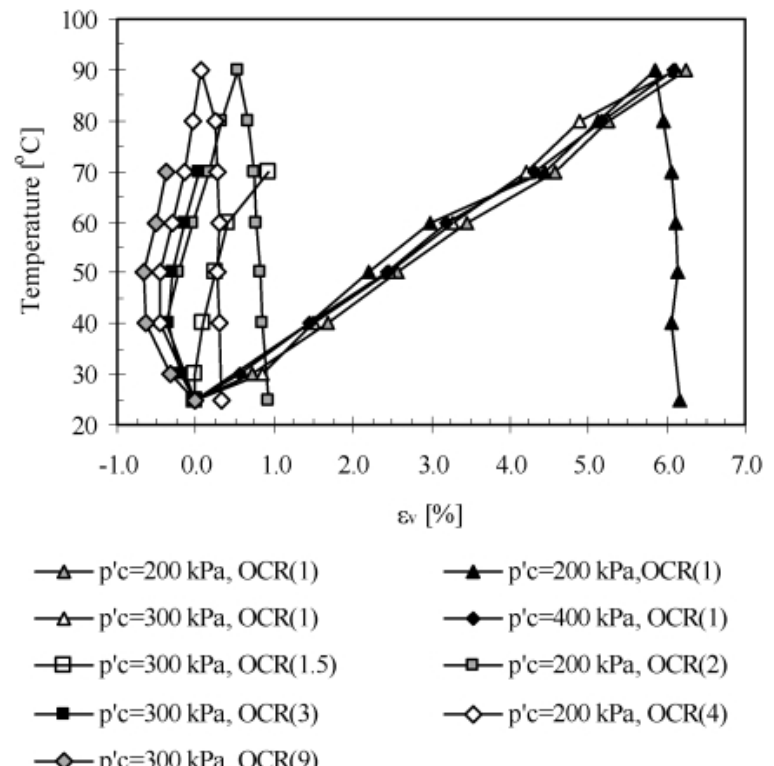

Fig. 6. Thermally induced volume change at different stress histories

under different isotropic stress conditions were subjected to incremental drained heating or drained heating/ cooling cycle at different temperature levels before conducting the shearing test. Figure 6 shows the thermally induced volume change of isotropic consolidated specimens at different stress conditions before shearing. The results of thermally induced volume change of normally consolidated clay illustrates stress level independent since the isotropic normally consolidated specimens at different preconsolidation pressures (200, 300, $400 \mathrm{kPa}$ ) show almost similar thermally induced volumetric strain. The reproducibility of the results was also confirmed by testing two normally consolidated specimens at same preconsolidation pressure $(200 \mathrm{kPa})$. In general, the test results show that the thermally induced volume change depends on stress history (OCR). As the soil changes from the normally consolidated state to the overconsolidated state, the thermally induced contractive volumetric strain keeps decreasing and beyond certain OCR value exhibits dilative behavior.

\section{Temperature Effect on Undrained Shear Strength Behav-} ior

Figure 7 shows the undrained shear strength test results of isotropic normally consolidated soft Bangkok clay specimens with preconsolidation pressure, $p_{\mathrm{c}}^{\prime}$, of $300 \mathrm{kPa}$ that were subjected to different drained heating levels $\left(25,70,90^{\circ} \mathrm{C}\right)$ before shearing. The undrained shear strength test results of overconsolidated specimens $\left(\mathrm{OCR}=1.5,3.0,9.0\right.$ and $\left.p_{\mathrm{c}}^{\prime}=300 \mathrm{kPa}\right)$ that were subjected to different elevated temperatures $\left(25,70^{\circ} \mathrm{C}\right)$ before shearing is shown in Fig. 8. The results are presented in the form of deviatoric stress $q$ and excess pore water pressure $\Delta u$, versus $\varepsilon_{\mathrm{a}}$; where $\varepsilon_{\mathrm{a}}$ is the axial strain. The results show that the undrained shear strength increased as the soil temperature increased whatever the overconsolidation ratios. In addition, for normally and lightly 

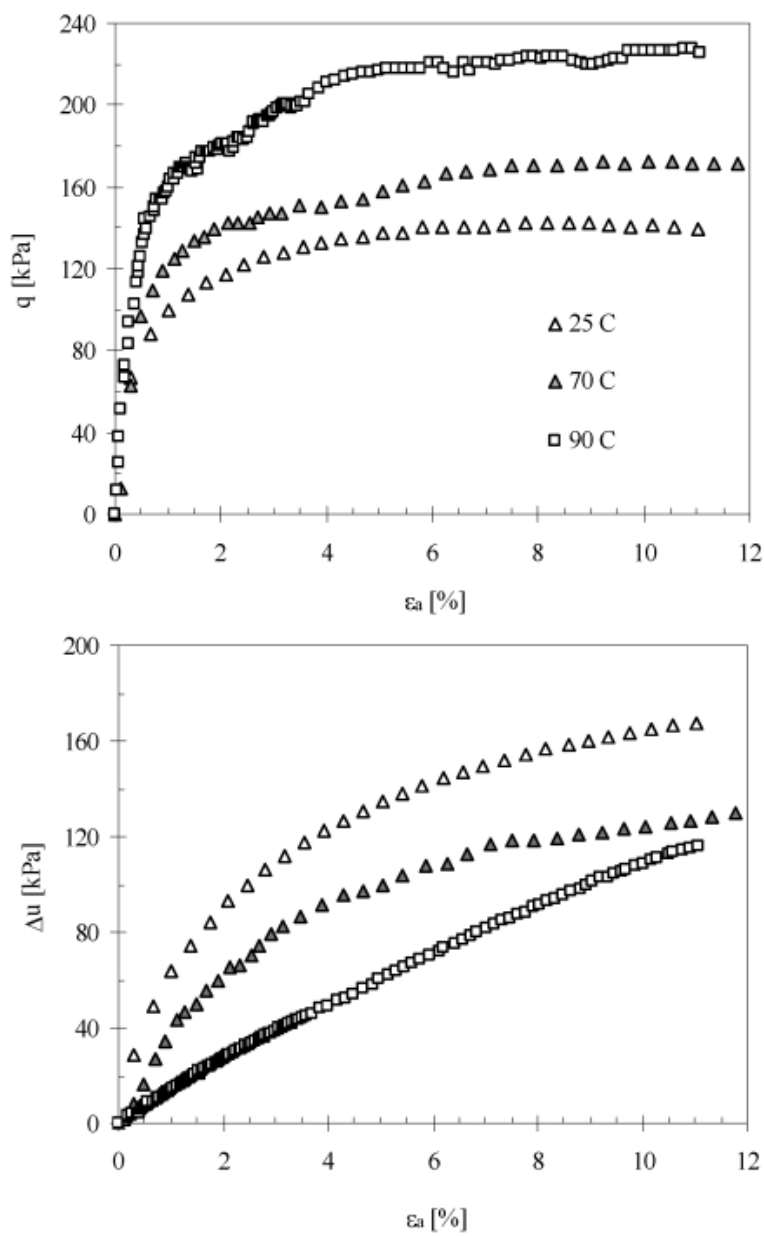

Fig. 7. Undrained compression triaxial test results of normally consolidated specimen $\left(p_{\mathrm{c}}^{\prime}=300 \mathrm{kPa}\right)$ at different elevated temperatures

overconsolidated specimens $(\mathrm{OCR}=1.5)$, the generated excess pore water pressure decreased as the soil temperature increased. However, for highly overconsolidated specimens as the soil temperature increased the excess pore water pressure increased as shown in Fig. 8 for specimens of $\mathrm{OCR}=3.0$ and 9.0.

Figure 9 demonstrates the undrained shear strength behavior of soft Bangkok clay specimens at different overconsolidation ratios $(1,2$, and 4$)$ that were subjected to different temperature histories ( 25 to 70 to $25^{\circ} \mathrm{C}$ and 25 to 90 to $25^{\circ} \mathrm{C}$ ) before shearing. The results show that shear strength increased as the maximum cycling temperature increased. The results also illustrate that as the soil temperature increased the excess pore water pressure decreased whatever the value of OCR. In order to investigate the difference between the undrained shear strength behavior of normally consolidated specimen when it is sheared at elevated temperature $(T)$, and when it subjected to temperature cycling $\left(T_{\mathrm{o}}-T-T_{\mathrm{o}}\right.$, where $T>T_{\mathrm{o}}$ and $T_{\mathrm{o}}$ is the room temperature), the results of normally consolidated specimen tested under both conditions are plotted in the form of normalized deviatoric stress $q / p_{\mathrm{c}}^{\prime}$ and normalized excess pore water pressure $\Delta u / p_{\mathrm{c}}^{\prime}$, versus $\varepsilon_{\mathrm{a}}$ as shown in Fig. 10. The peak deviatoric stress increased
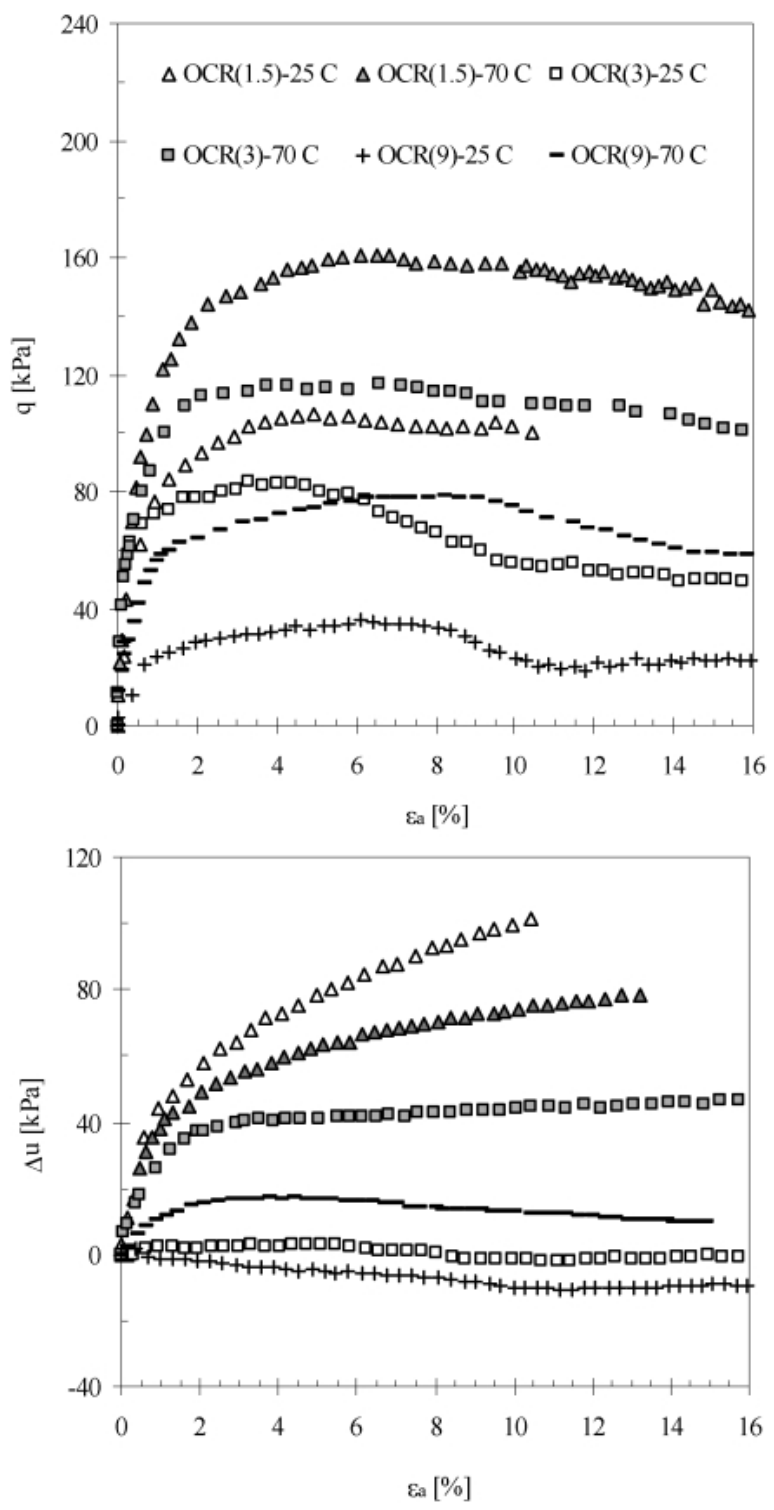

Fig. 8. Undrained compression triaxial test results of overconsolidated specimens $\left(p_{\mathrm{c}}^{\prime}=300 \mathrm{kPa}\right)$ at different elevated temperatures

with increase in soil temperature. Additionally, it can be noted that the specimen subjected to temperature cycling before shearing showed similar increase in the peak deviatoric stress. However, the axial strain at the peak deviatoric stress for the specimen subjected to temperature cycling before shearing is lower than the specimen sheared at elevated temperature. Figure 10 also illustrates that the excess pore pressure decreased as the soil temperature increased for both type of specimen. Therefore, for a normally consolidated specimen a temperature increase before shearing resulted in an irreversible increase of undrained peak deviatoric stress.

\section{Temperature Effect on Drained Shear Strength Behavior}

The results of the drained compression triaxial shear tests conducted on specimens of $300 \mathrm{kPa}$ preconsolidation pressure at different $\mathrm{OCR}$ values $(1,2,4,8)$ and heated to different temperatures $\left(25,70,90^{\circ} \mathrm{C}\right)$ are plotted in Fig. 11. The results show that the specimens 

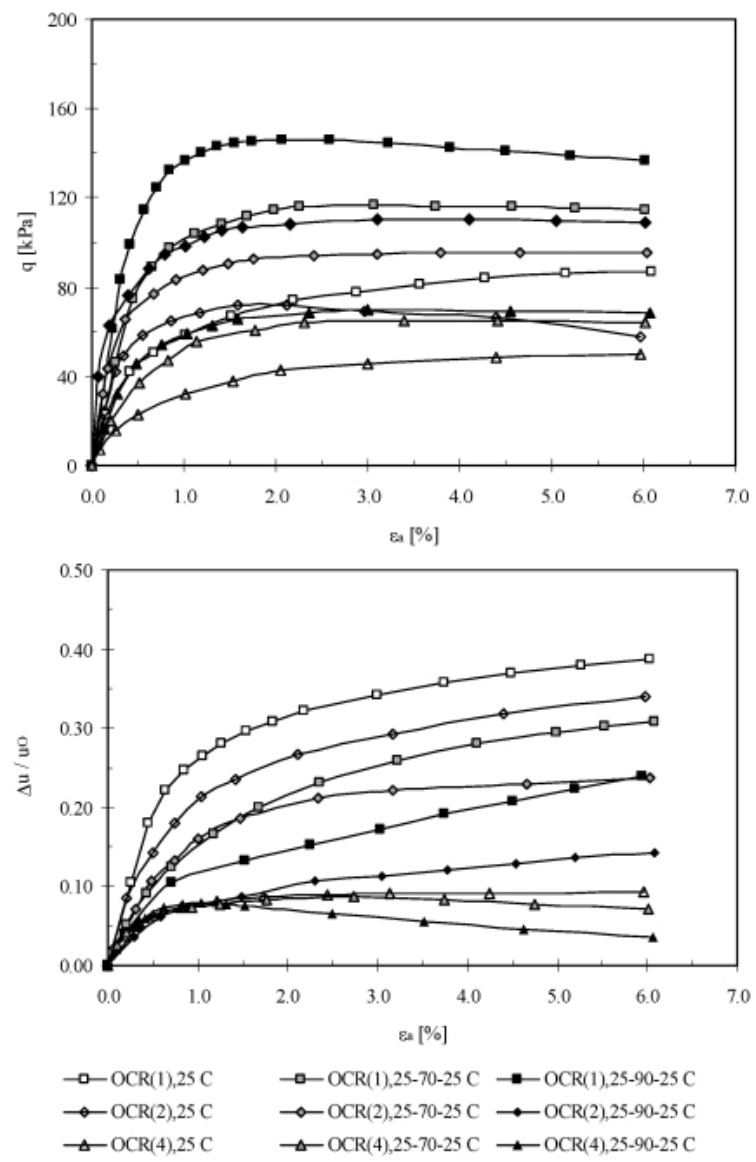

Fig. 9. Undrained compression triaxial test results of normally and overconsolidated specimens $\left(p_{\mathrm{c}}^{\prime}=200 \mathrm{kPa}\right)$ after subjecting to different heating/cooling cycles

sheared at higher temperatures sustained higher peak deviatoric stresses. It can also be noted that normally consolidated specimen tested at room temperature exhibited strain hardening behavior while specimens tested at elevated temperatures exhibited strain softening behavior.

In general, the results in Fig. 11 show that at large strains i.e., the residual deviatoric stress of the soil is independent of temperature. Similar behavior has been observed by Cekerevac and Laloui (2004) for remolded normally consolidated CM clay specimens sheared under drained condition at elevated temperature of $90^{\circ} \mathrm{C}$. Additionally, it can also be noted from Fig. 11 that the normally consolidated specimens sheared at higher temperature have lower volumetric strain whereas the volume change behavior of overconsolidated specimens sheared at different elevated temperatures has no clear trend.

\section{Effect of Temperature on Stress-Strain Modulus}

The actual measurement of stress-strain modulus, $E$, from stress-strain graph is an arbitrary affair. An initial tangent modulus or at a stress level equal to one-half of the peak deviatoric stress, $q_{\mathrm{f}}=\left(\sigma_{1}-\sigma_{3}\right)_{\mathrm{f}}$, are the common approach. In this study, $E$ was measured at different deviatoric stress level ratios $q_{\mathrm{f}} / q$ and normalized with respect to the mean effective stress, $p$, as suggested by
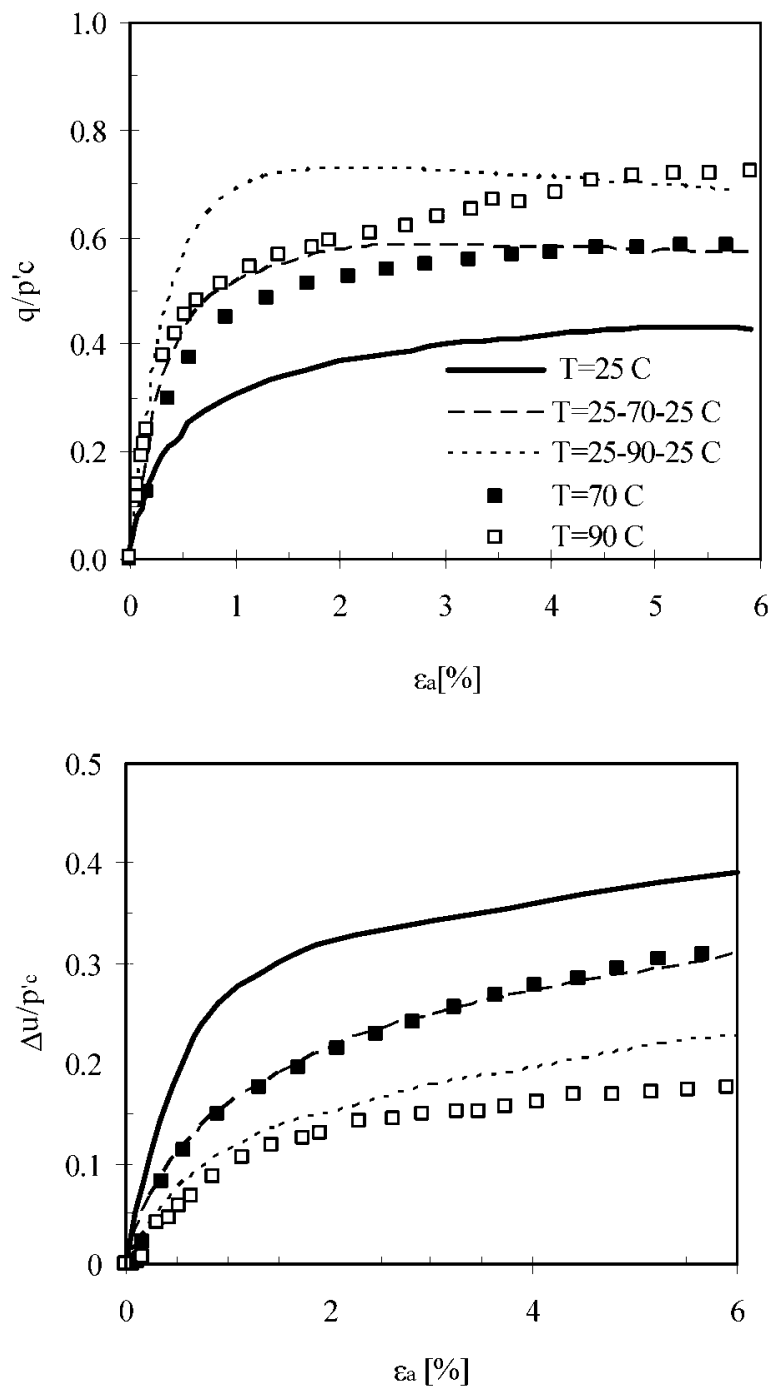

Fig. 10. Undrained triaxial compression test results on normally consolidated soil at different temperatures and heating/cooling cycles

Ladd (1964). The effects of the temperature and the temperature history on the undrained and drained secant stress-strain modulus of normally consolidated specimens are shown in Fig. 12. The results show that the normalized undrained secant stress-strain modulus increased as the temperature increased. Moreover, the modulus of the specimens that have temperature history before shearing is higher than those sheared at elevated temperature. Figure 12 also shows that specimens sheared under drained condition exhibited higher secant stress-strain modulus as the test temperature increased.

\section{Effect of Temperature on Critical State Line}

The critical state is known as the perfect plastic condition that can be expressed by $\left(\partial p / \partial \varepsilon_{\mathrm{v}}\right) \approx\left(\partial q / \partial \varepsilon_{\mathrm{s}}\right) \approx\left(\partial \varepsilon_{\mathrm{v}} /\right.$ $\left.\partial \varepsilon_{\mathrm{s}}\right) \approx 0.0$. The effect of temperature on behavior of soft Bangkok clay was evaluated based on the drained and undrained triaxial test results conducted at different temperature levels $\left(25,70,90^{\circ} \mathrm{C}\right)$. Figure 13 shows that the slope of the critical state line in $q-p$ plane, $M$, is temperature independent with value of 0.8 . However, the 

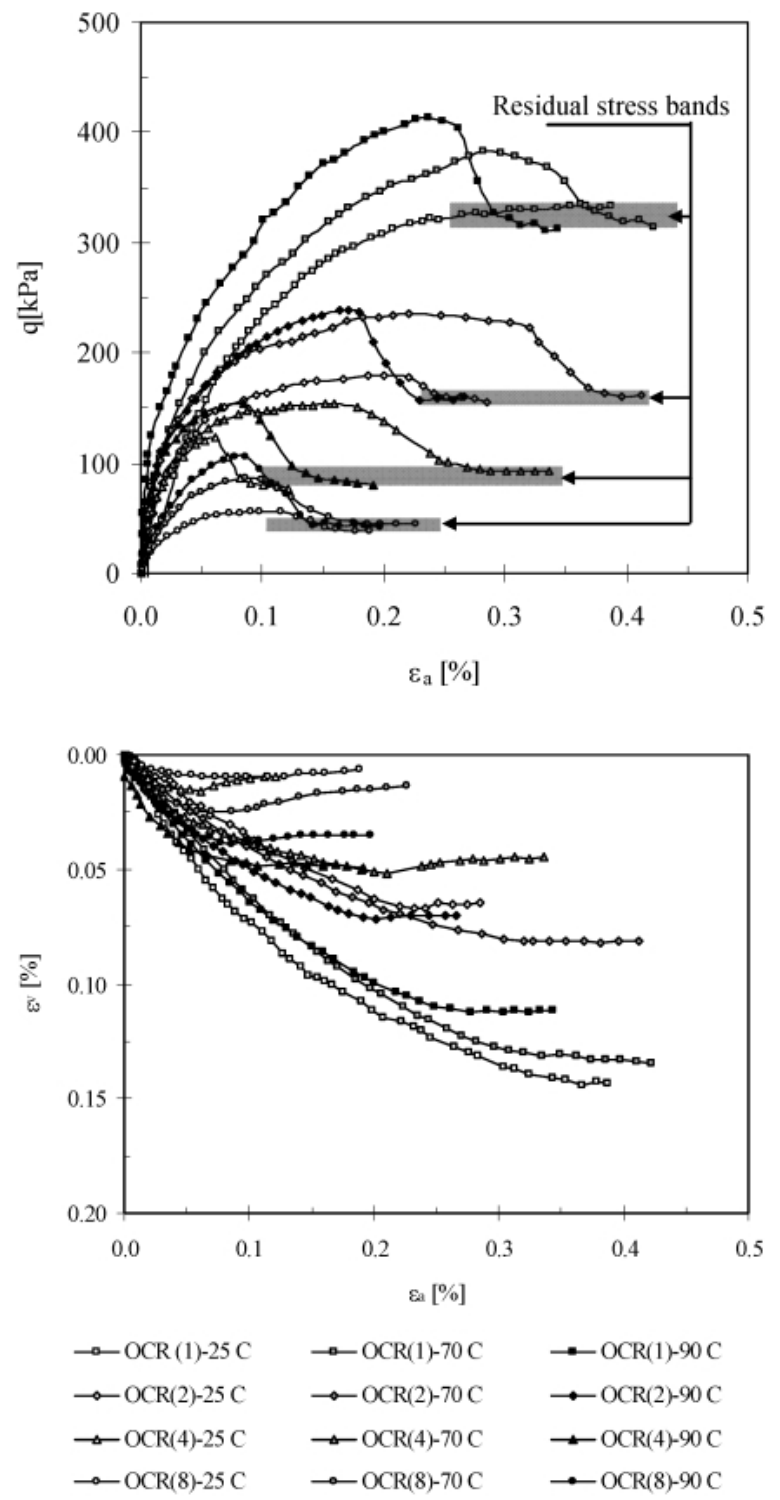

Fig. 11. Drained triaxial compression test results of soft Bangkok clay isotropic consolidated specimens at different OCR and temperatures levels

results shown in Fig. 14 does not give clear trend for the behavior of critical state line in the volumetric plane $(e-\log [p])$ at elevated temperatures. The expected experimental scatters and difficulty to get identical undisturbed soil specimens can hide the real behavior in volumetric plane.

\section{Temperature Effect on Normalization Concept}

According to conventional soil mechanics, at room temperature, the results of undrained triaxial tests on family of isotropically normally consolidated clay specimens, each specimen being compressed to different preconsolidation pressures, shows higher values of $q$ at failure for specimen which was consolidated to higher values of $p_{c}^{\prime}$, but the shape of the $q-\varepsilon_{\mathrm{a}}$ curves are approximately similar for all the tests. Thus, it was possible to normalize the $q-\varepsilon_{\mathrm{a}}$ curves by plotting $q / p_{\mathrm{c}}^{\prime}$ against $\varepsilon_{\mathrm{a}}$, as shown in Fig. 15. The normalization of the undrained

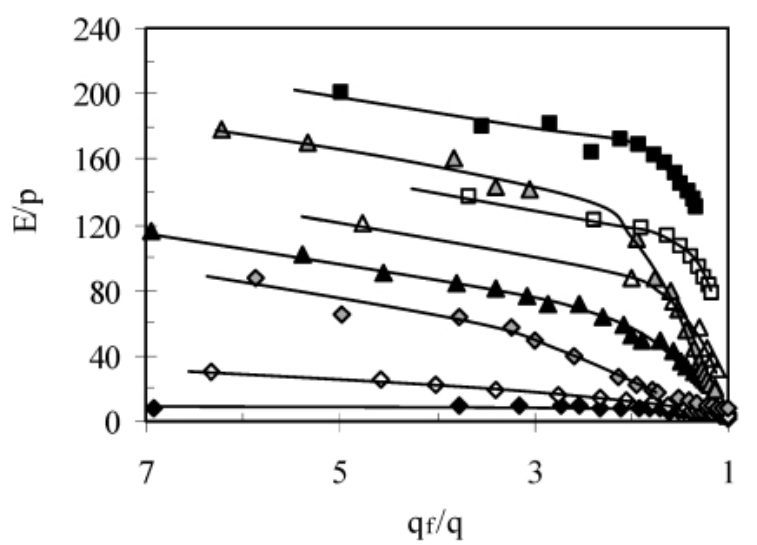
$\Delta \mathrm{U}, \mathrm{T}=25^{\circ} \mathrm{C}$
$\Delta \mathrm{U}, \mathrm{T}=70^{\circ} \mathrm{C}$
$\Delta \mathrm{U}, \mathrm{T}=90^{\circ} \mathrm{C}$
- D, $\mathrm{T}=25^{\circ} \mathrm{C}$
$\diamond \mathrm{D}, \mathrm{T}=70^{\circ} \mathrm{C}$
$\diamond \mathrm{D}, \mathrm{T}=90^{\circ} \mathrm{C}$
口 $\mathrm{U}, \mathrm{T}=25-70-25^{\circ} \mathrm{C}$
- $\mathrm{U}, \mathrm{T}=25-90-25^{\circ} \mathrm{C}$

Fig. 12. Effect of temperature and temperature history on undrained (U) and drained (D) secant modulus of normally consolidated soft Bangkok clay

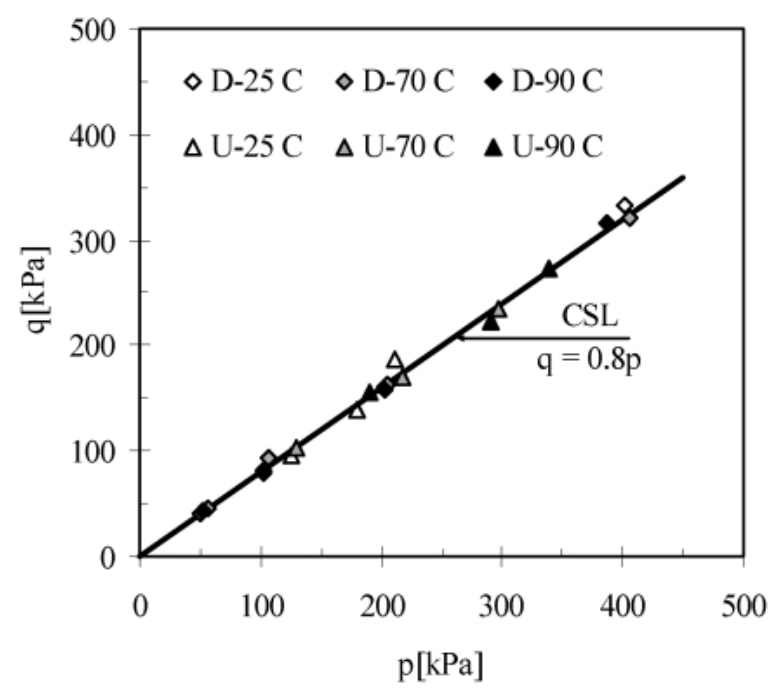

Fig. 13. Effect of temperature on the slope of the critical state line in the deviatoric plane $(q: p)$

triaxial test results conducted on family of isotropically normally consolidated clay specimens that compressed to different preconsolidation pressures $(200,300,400 \mathrm{kPa})$ and heated under drained condition up to different temperature levels $\left(25,70,90^{\circ} \mathrm{C}\right)$ before shearing validated the normalization concept at different temperature levels as shown in Fig. 15.

\section{DISCUSSIONS OF ANISOTROPIC CONSOLIDATION TEST RESULTS}

Effect of Temperature on the Compression Line, $\lambda$

Figure 16 shows the anisotropic consolidation test results at different temperatures plotted in $\varepsilon_{\mathrm{v}}-\log (p)$ and $\varepsilon_{\mathrm{s}}-\log (q)$, where $\varepsilon_{\mathrm{v}}$ and $\varepsilon_{\mathrm{s}}$ are the volumetric and shear strain, respectively. The results show that the slope of the 


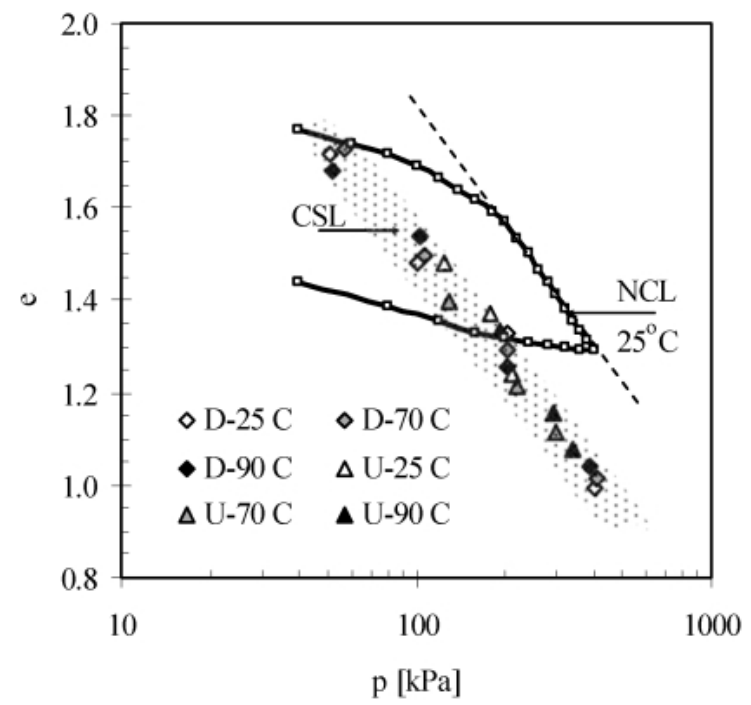

Fig. 14. Effect of temperature on the critical state line in the volumetric plane

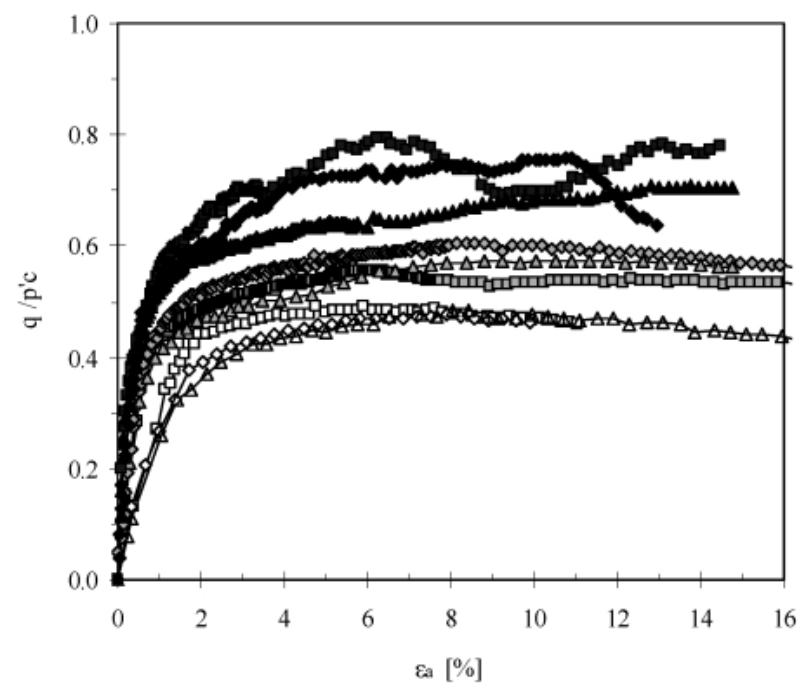

$25^{\circ} \mathrm{C} \Rightarrow 0-p^{\prime} \mathrm{c}=200 \mathrm{kPa} \multimap \mathrm{p}^{\prime} \mathrm{c}=300 \mathrm{kPa} \triangle \mathrm{p}^{\prime} \mathrm{c}=400 \mathrm{kPa}$ $70^{\circ} \mathrm{C} \Rightarrow-p^{\prime} \mathrm{c}=200 \mathrm{kPa} \longrightarrow \mathrm{p}^{\prime} \mathrm{c}=400 \mathrm{kPa} \longrightarrow \mathrm{p}^{\prime} \mathrm{c}=300 \mathrm{kPa}$ $90^{\circ} \mathrm{C} \Rightarrow-p^{\prime} \mathrm{c}=200 \mathrm{kPa} \longrightarrow \mathrm{p}^{\prime} \mathrm{c}=300 \mathrm{kPa} \longrightarrow \mathrm{p}^{\prime} \mathrm{c}=400 \mathrm{kPa}$

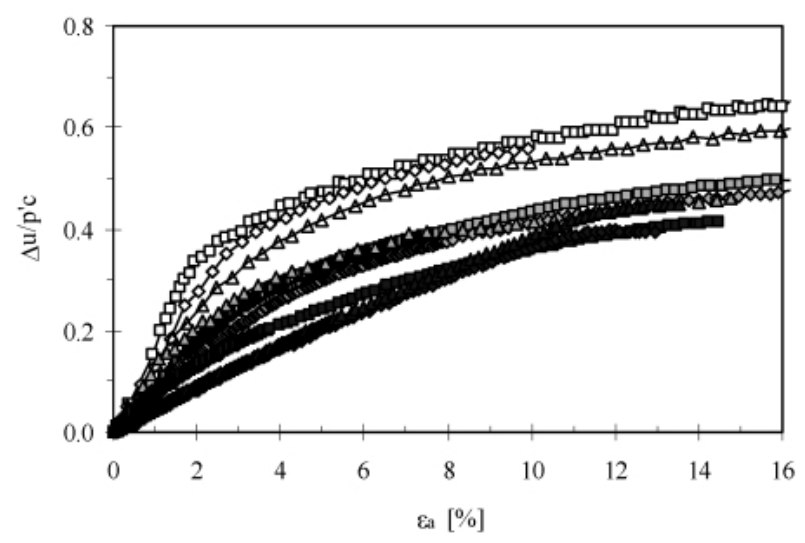

Fig. 15. Normalization of undrained triaxial test results of normally consolidated specimens with preconsolidation pressure $\left(p_{c}^{\prime}\right)$ at different temperature levels compression line is temperature independent because it moved towards the left side as the soil temperature increased. This movement reduced the size of the elastic zone as the soil temperature increased. This feature can be conveniently expressed by the thermal evolution of the preconsolidation pressure at constant plastic strain condition (swelling line). Figure 17 shows the thermal evolution of preconsolidation pressure at constant plastic strain condition of different constant stress ratio consolidation tests plotted in $p_{\mathrm{c}}(T) / p_{\mathrm{c}}\left(T_{\mathrm{o}}\right)-T$ graph. The term $p_{\mathrm{c}}(T)$ and $p_{\mathrm{c}}\left(T_{\mathrm{o}}\right)$ are the preconsolidation pressure at test temperature $T$ and room temperature $T_{\mathrm{o}}$, respectively, at constant plastic strain condition. The results show that the thermal reduction of the elastic zone size decreased as the constant stress ratio of the test, $\eta$ (eta), increased.

\section{Effect of Temperature on the Swelling Line, $\kappa$}

The results of Fig. 16 also show that the slope of the reloading swelling line is temperature dependent. Similar conclusion was reported by Eriksson (1989). On the other hand, Campanella and Mitchell (1968) and Hueckel and Baldi (1990) have shown that the slope of the swelling line is temperature independent. This discrepancy can be explained in terms of the differences in the test procedures adopted by each researcher. Campanella and Mitchell (1968) and Hueckel and Baldi (1990) adopted unloading test procedure for pre-heated normally consolidated clay whereas Eriksson (1989) used reloading test procedure of pre-heated highly overconsolidated clay.

In order to thoroughly analyze the influence of test procedure on thermal evolution of the swelling line, two undisturbed soft Bangkok clay specimens have been subjected to isotropic consolidation pressure equal to $200 \mathrm{kPa}$ and unloaded to $40 \mathrm{kPa}(\mathrm{OCR}=5)$ at $25^{\circ} \mathrm{C}$. At the end of the unloading process, one of the specimens has been subjected to $70^{\circ} \mathrm{C}$. Afterwards, both specimens have been subjected to incremental isotropic mechanical reloading up to $400 \mathrm{kPa}$ followed by incremental mechanical unloading as shown in Fig. 18. The results show that at elevated temperature the slope of the reloading line is temperature dependent while the slope of the unloading line is temperature independent. This result further explains that observed discrepancy in the literature is due to difference in the test procedures. The temperature behavior of reloading line can be attributed to the existence of thermal yield limit within the conventional elastic zone that generated irreversible thermally induced volume change as the consolidation stress increased (Cui et al., 2000). Thus, as the swelling line expresses the elastic behavior of soils within the yield limit, the reloading line is not valid to represent the swelling line since it did not acquire similar slope as the unloading line. Consequently, the thermal behavior of swelling line should be evaluated based on the unloading line behavior which shows that the swelling line can be considered as temperature independent.

\section{Effect of Temperature on Yield Limit}

The effect of temperature on the yield limit in $q$ - $p$ plane 

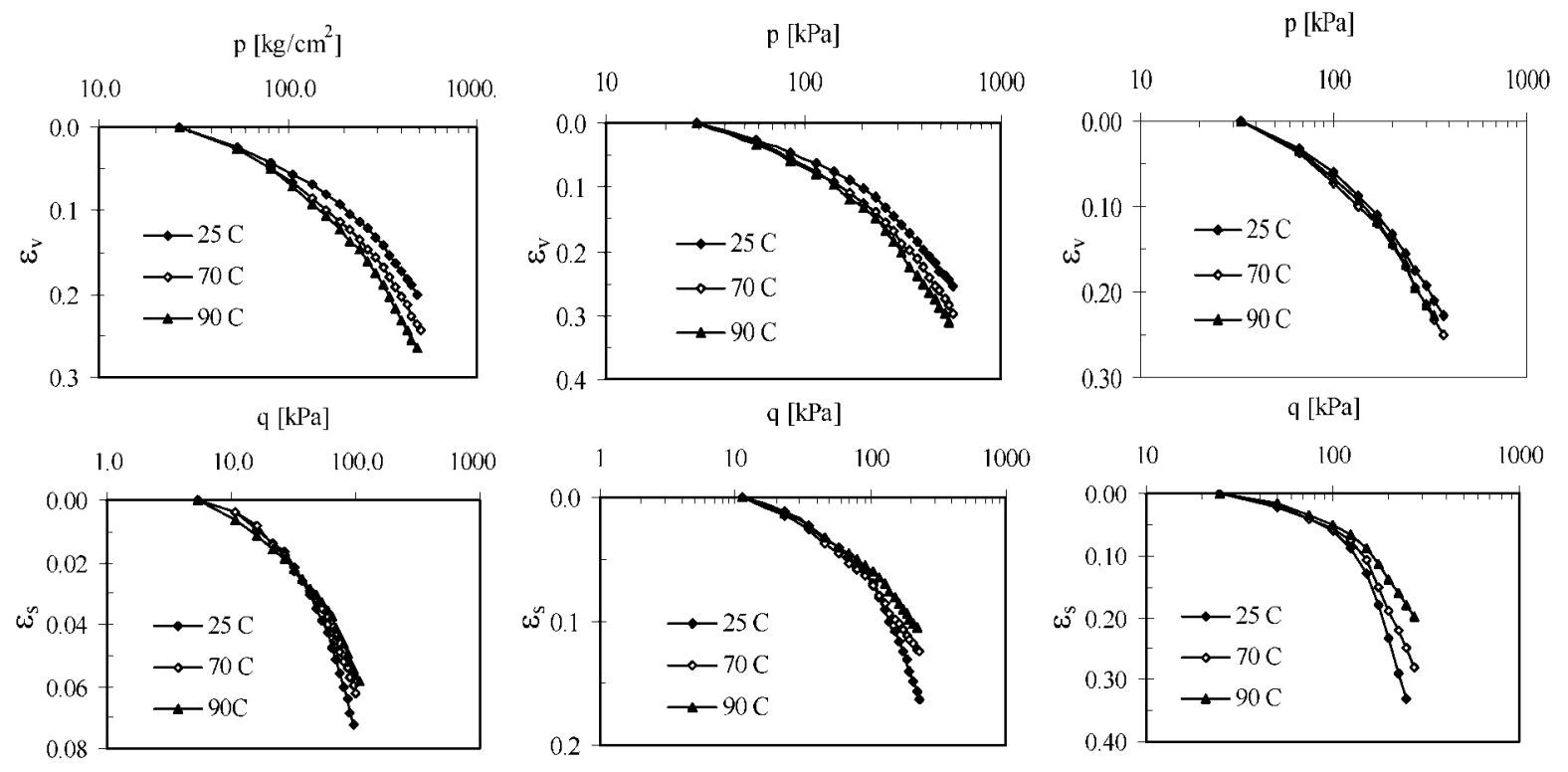

a) $\eta=0.2$

b) $\eta=0.4$

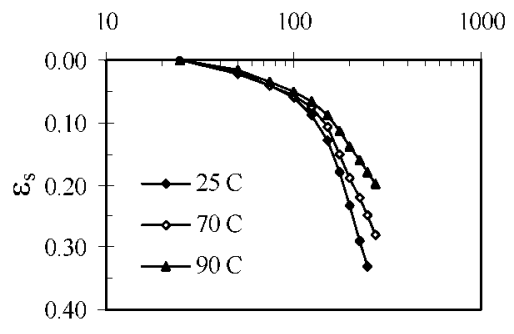

c) $\eta=0.75$

Fig. 16. Anisotropic consolidation test results at different constant stress ratios $(\eta)$ and temperature levels

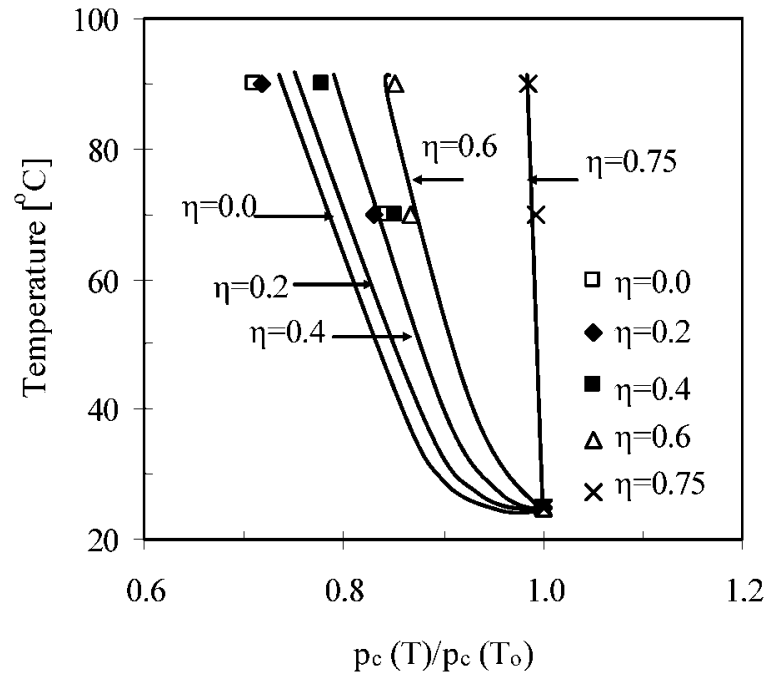

Fig. 17. Temperature effect on the size of the elastic zone at constant plastic strain condition as function of constant stress ratio $\eta$

was investigated by determining the preconsolidation pressure for each constant stress ratio consolidation test at different elevated temperatures. Grozic et al. (2003) analyzed the different methods for determining preconsolidation pressure and show that the strain energy methods proposed by Crook and Graham (1976) provided the most consistent overall results. Therefore, the strain energy method was used in this study to determine accurately the temperature effect on preconsolidation pressure. The strain energy, $W$, can be decomposed into volumetric $\left(W_{\mathrm{v}}\right)$ and shear $\left(W_{\mathrm{s}}\right)$ strain energies as follows:

$$
W=W_{\mathrm{v}}+W_{\mathrm{s}}=\int p d \varepsilon_{\mathrm{v}}+\int q d \varepsilon_{\mathrm{s}}
$$

where:

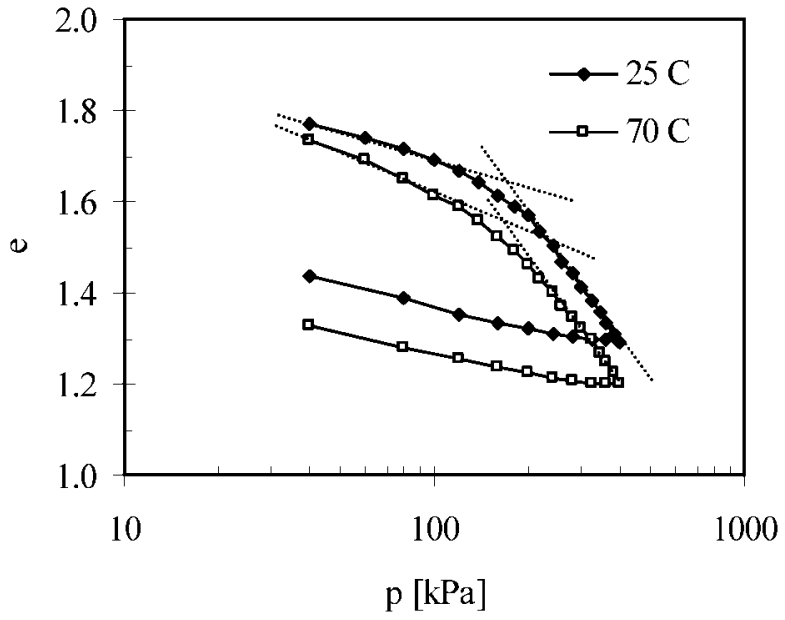

Fig. 18. Temperature effect on the slope of swelling line, $\kappa$

$$
\begin{aligned}
& W_{\mathrm{v}}=\Sigma \frac{p_{\mathrm{i}}+p_{(\mathrm{i}+1)}}{2}\left[\varepsilon_{\mathrm{v}(\mathrm{i}+1)}-\varepsilon_{\mathrm{v}(\mathrm{i})}\right] \\
& W_{\mathrm{s}}=\Sigma \frac{q_{\mathrm{i}}+q_{(\mathrm{i}+1)}}{2}\left[\varepsilon_{\mathrm{s}(\mathrm{i}+1)}-\varepsilon_{\mathrm{s}(\mathrm{i})}\right]
\end{aligned}
$$

The plot of the strain energy $(W)$-mean effective stress $(p)$ relationship, using arithmetic scales can be approximated or fitted using linear relationships. The intersections of these fitted lines provide the preconsolidation pressure. Figure 19 shows $W-p$ plot for the tests with constant stress ratios of 0.2 and 0.6 conducted at different elevated temperatures $\left(25,70,90^{\circ} \mathrm{C}\right)$. The yield points obtained for each constant stress ratio consolidation test at different temperatures are plotted in the mean effective stress $(p)$-void ratio $(e)$ and the $q-p$ planes as shown in Fig. 20. The test results indicated that the preconsolida- 

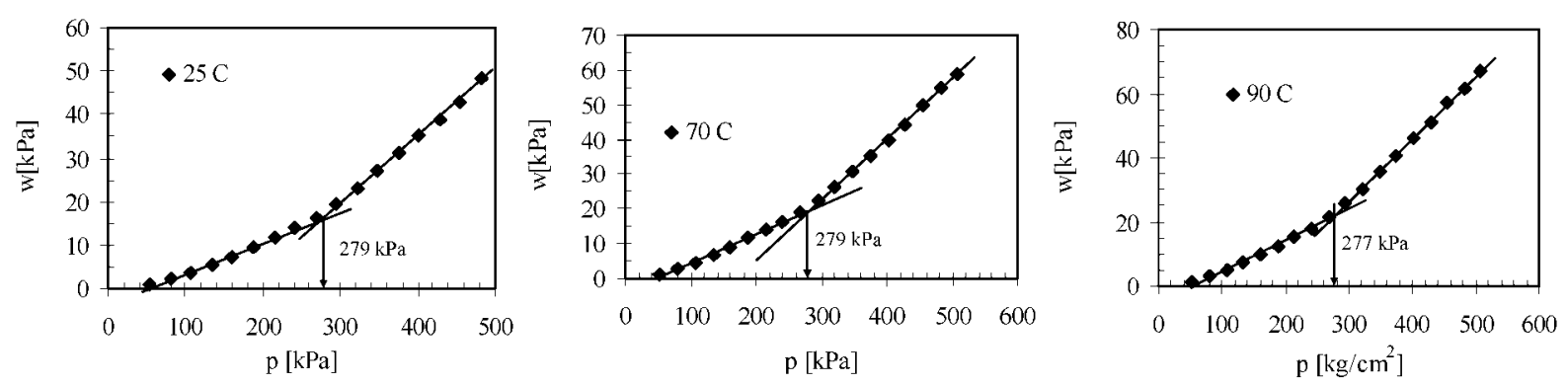

a) $\eta=0.2$
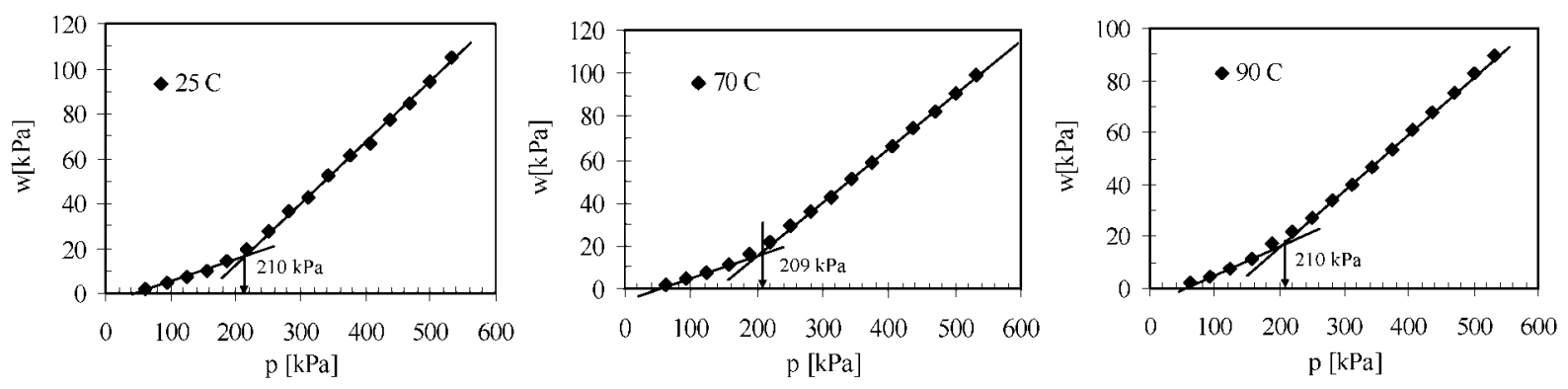

b) $\eta=0.6$

Fig. 19. Determination of the preconsolidation pressure using strain energy approach

tion pressure is temperature independent while the corresponding specific volume $(v=1+e)$ is temperature dependent because it decreased as the testing temperature increased.

According to Modified Cam-Clay theory (Wood, 1990), the yield locus is the intersection of the elastic wall with the state of boundary surface (SBS). Moreover, the swelling line $\kappa$ is the yield locus trace on the isotropic plane $(v-p)$. The yielding points at different temperature levels plotted in $v-p$ plane shows that only the room temperature yield points constructed the swelling line $\kappa$. In the other two temperature levels $\left(70,90^{\circ} \mathrm{C}\right)$, the constructed lines have slopes greater than the swelling line $\kappa$ as shown in Fig. 20(b). Therefore, the yield points at elevated temperatures are located on the SBS but did not belong to unique yield locus. This behavior can be attributed to the generated irreversible thermally induced volume change within the conventional elastic zone (Cui et al., 2000).

The yield points at different elevated temperatures (Fig. 20) can be utilized to determine the constant volume cross section of Roscoe surface by normalizing the stress values of yield points by the equivalent pressure, $p_{\mathrm{e}}$. This normalization approach can be also applied to the drained and undrained triaxial tests results of normally consolidated specimens conducted at different elevated temperature levels to determine the constant volume cross section of Roscoe surface. The normalization results form different experiments are plotted in Fig. 21. The results show acceptable agreement between the results of different test types. At elevated temperatures the Roscoe surface becomes steeper as the peak deviatoric stress increased and the ratio between the initial mean a)

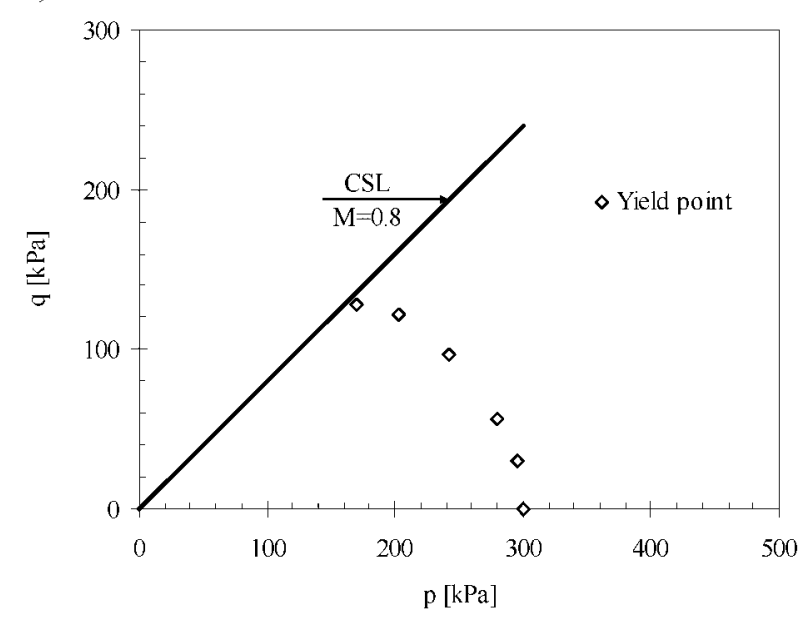

b)

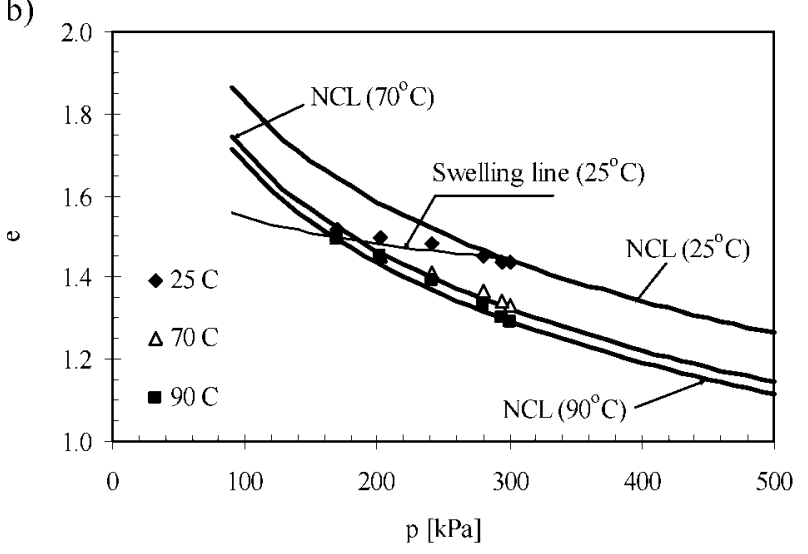

Fig. 20. Yield points obtained from anisotropic consolidation tests plotted in deviatoric and volumetric plane 


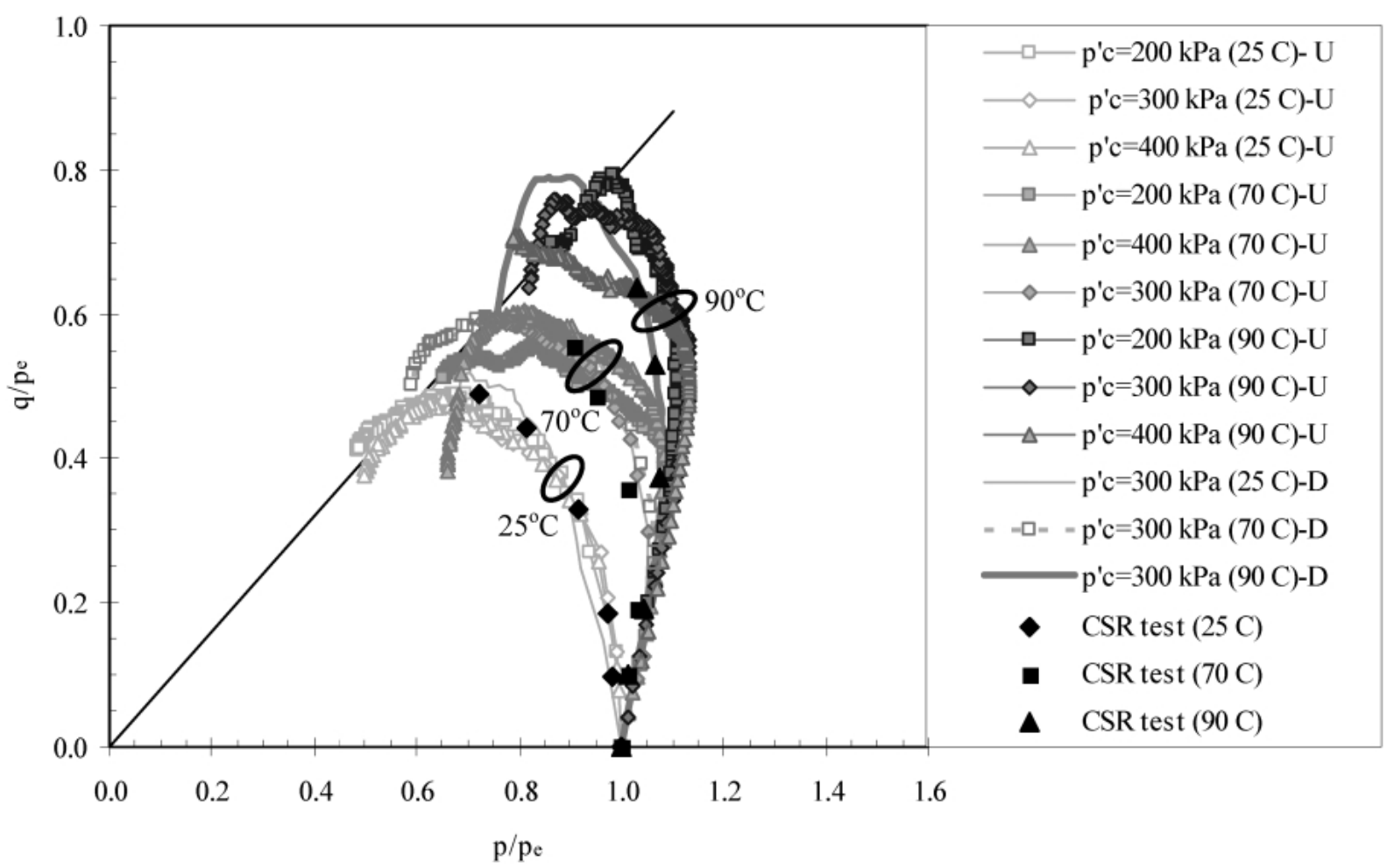

Fig. 21. Effect of temperature on constant volume section of Roscoe surface obtained from anisotropic consolidation tests

effective stress and the peak mean effective stress decreased.

\section{Effect of Temperature on Flow Rule}

The anisotropic consolidation test results can be also used to investigate the temperature effect on the flow rule. The plastic strain increments ratio $\left(d \varepsilon_{v}^{\mathrm{p}} / d \varepsilon_{\mathrm{s}}^{\mathrm{p}}\right)$ was determined for each constant stress ratio test in the post yield zone. As the post yield strain comprises an elastic component, the plastic strain increment was calculated as follows:

$$
\begin{gathered}
\delta \varepsilon_{\mathrm{v}}^{\mathrm{p}}=\delta \varepsilon_{\mathrm{v}}-\delta \varepsilon_{\mathrm{v}}^{\mathrm{e}} \\
\delta \varepsilon_{\mathrm{s}}^{\mathrm{p}}=\delta \varepsilon_{\mathrm{s}}-\delta \varepsilon_{\mathrm{s}}^{\mathrm{e}}
\end{gathered}
$$

where $\delta \varepsilon_{v}^{\mathrm{p}}$ and $\delta \varepsilon_{\mathrm{s}}^{\mathrm{p}}$ are the volumetric and shear plastic strain increments, respectively, $\delta \varepsilon_{v}^{\mathrm{e}}$ and $\delta \varepsilon_{\mathrm{s}}^{\mathrm{e}}$ are the volumetric and shear elastic strain increments, respectively, and $\delta \varepsilon_{\mathrm{v}}$ and $\delta \varepsilon_{\mathrm{s}}$ are the total volumetric and shear strain increments, respectively. The elastic volumetric and shear strain were estimated by extrapolating the elastic line in $\varepsilon_{v}-\log (p)$ and $\varepsilon_{\mathrm{s}}-\log (q)$ plots, respectively. Figure 22 shows the effect of temperature on the plastic strain increment ratio $\left(d \varepsilon_{v}^{\mathrm{p}} / d \varepsilon_{\mathrm{s}}^{\mathrm{p}}\right)$ at different stress ratios $\eta$. The results indicated that for isotropic stress condition $(\eta=$ 0.0 ), the soft Bangkok clay does not present plastic shear strain at different temperature levels. However, for the other stress ratios, the results indicate that as the soil temperature increased the plastic strain increment ratio $\left(d \varepsilon_{\mathrm{v}}^{\mathrm{p}} / d \varepsilon_{\mathrm{s}}^{\mathrm{p}}\right)$ also increased. These findings suggest that the flow rule is temperature dependent.

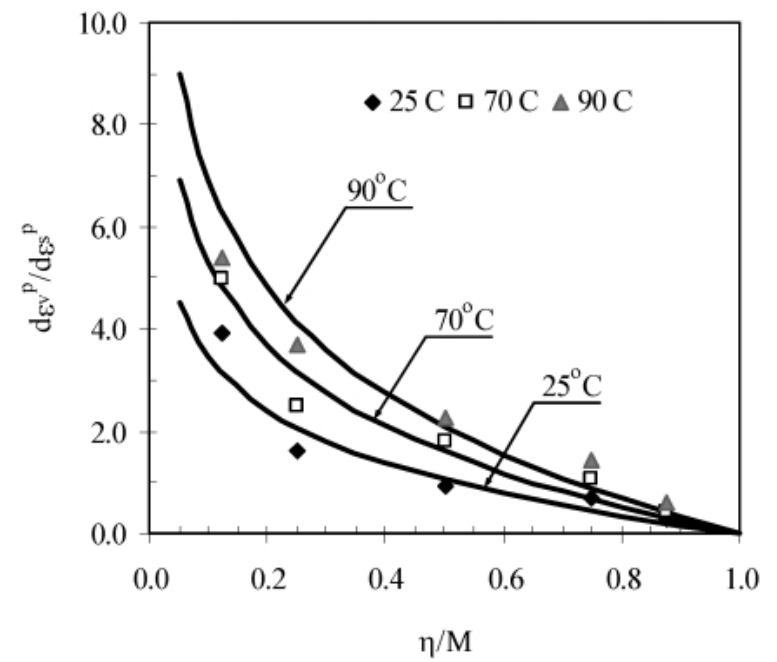

Fig. 22. Effect of temperature on plastic strain increment ratio

\section{INTERPRETATION OF TEMPERATURE EFFECT ON VOLUME CHANGE AND SHEAR STRENGTH BEHAVIOUR}

Abuel-Naga et al. (2006b) interpreted the thermally induced volume change behaviour based on the temperature effects on the clay interparticle forces and viscous shear resistance of adsorbed water that affect the clay particles resistance to fabric changes. The expansion thermally induced volume change behaviour at highly overconsolidation condition was attributed to the thermal expansion of clay minerals (Campanella and Mitchell, 1968), and the temperature effect on the interparticle 


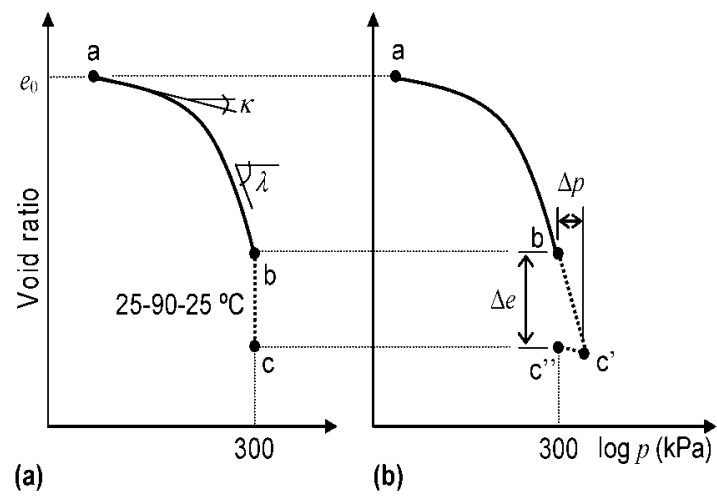

Fig. 23. Equivalent mechanical cycle for heating/cooling cycle

physico-chemical forces which have reversible behaviour. The irreversible contraction thermally induced volume change behaviour at normally consolidated condition was attributed to the thermally induced reduction in the clay particles resistance to fabric changes which result in irreversible volume change behaviour. The magnitude of this type of volume change is stress history dependent. It decreases as the OCR value increases and completely vanishes at certain overconsolidation condition. Therefore, this irreversible volume change behaviour can not be observed at highly overconsolidation condition. More explanation for this behaviour is given in Abuel-Naga et al. (2006b)

Thermally induced increase in the shear strength and stiffness can be attributed to the thermally induced volume change, as shown in Fig. 6, and the thermally induced fabric changes. Microscopic studies performed by Pusch and Güven (1990) on Na-bentonite under elevated temperatures have shown irreversible microstructural rearrangement in the form of denser grouping of the stacks of the montmorillonite flakes which normally associated with permanent increase in the mechanical strength and stiffness. The results of Leroueil et al. (1979) and Sivakumar et al. (2002) confirmed the influence of the soil structure (fabric) on the strength and yielding behavior.

Indirect quantification of the share of the thermally induced volume change and the fabric change was conducted in this study. The compression undrained triaxial test results of four identical specimens that were consolidated isotropically up to $300 \mathrm{kPa}$ and subjected to either heating/cooling or equivalent mechanical load cycle before sheared under undrained condition were used. The first specimen was sheared at room temperature $\left(25^{\circ} \mathrm{C}\right)$ and was used as the reference test. The second specimen was subjected to heating/cooling cycle ( 25 to 90 to $25^{\circ} \mathrm{C}$ ) before shearing as shown in Fig. 23(a). The last two specimens were subjected to equivalent mechanical load cycle that induces volume change equal to the thermally induced volume change of the first specimen (Fig. 23(b)). Two specimens have been used under this path in order to check the consistency of the results. Figure 24(a) shows the test results of average peak shear strength with cyclic equivalent mechanical loading is substantially lower than
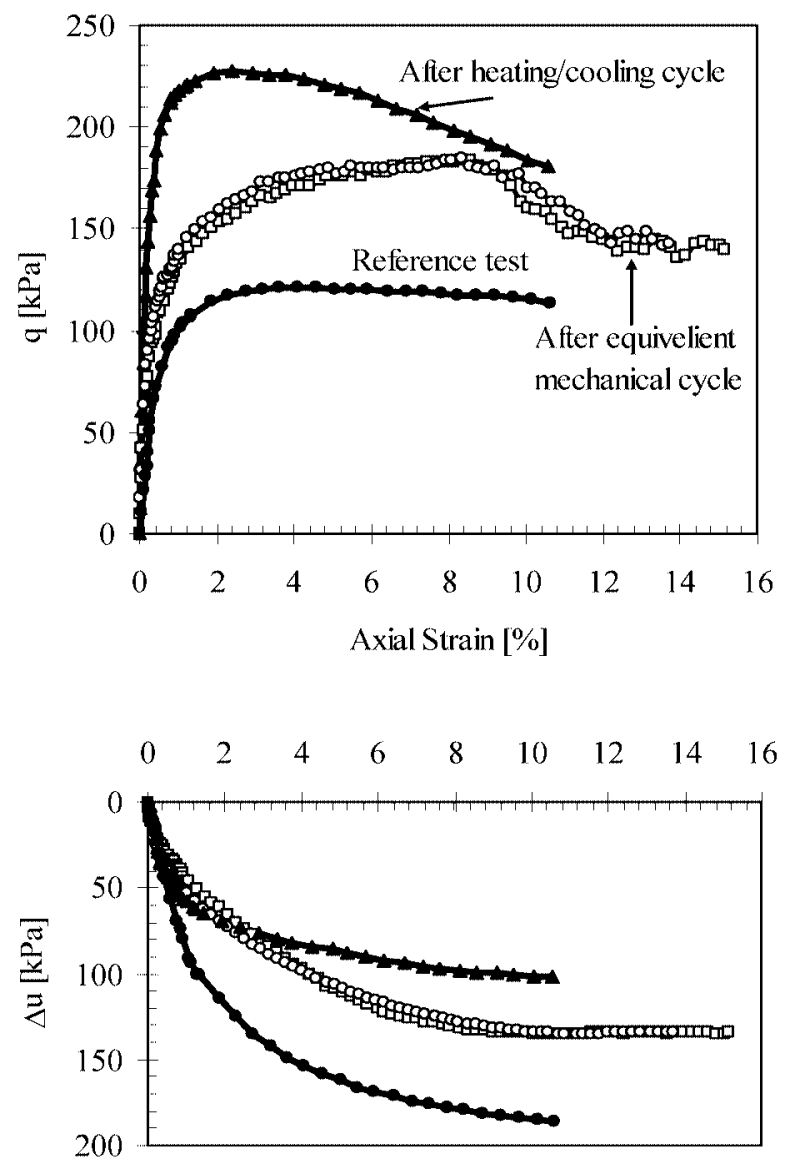

Fig. 24. Undrained shear test results for specimens subjected to heating/cooling cycle $\left(25\right.$ to 90 to $\left.25^{\circ} \mathrm{C}\right)$ and equivalent mechanical cycle

with cyclic thermal loading indicating that strength induced by volume change alone could not be the only source of the thermo-mechanically induced increase in the soil's strength. It can also be observed that the peak strength for these cyclic mechanical loading only developed at a larger strain in contrast to the behavior of the heated specimen in which the peak strength developed at lower strain level. Figure 24(b) shows that the corresponding generated excess pore water pressure for the specimen subjected to cyclic mechanical loading only is higher than that of the heated one. Comparing the shear strength peak values of these tests, it can be shown that the strength induced by thermal volumetric change amounts to about $60 \%$ of the total thermo-mechanically induced shear strength. Thus, the remaining approximately $40 \%$ strength can be attributed to the thermally induced fabric changes.

\section{CONCLUSIONS}

Based on the results of the intensive experimental program using modified triaxial apparatus, the temperature effects on the mechanical behavior of soft Bangkok clay within the range of 25 to $90^{\circ} \mathrm{C}$ can be concluded as follows:

- The temperature induced volume change of isotropic consolidating specimens is stress history dependent 
and stress level independent. As the soil changes from the normally consolidated state to the overconsolidated state, the thermally induced contractive volumetric strain keeps decreasing and beyond certain OCR value exhibits dilative behavior.

- The thermally induced volume change behavior can be interpreted based on the temperature effects on the clay interparticle forces and viscous shear resistance of adsorbed water that affect the clay particles resistance to fabric changes.

- The stiffness, and undrained and drained shear strength is temperature dependent because they increased as the soil temperature increased or after subjected to a temperature history.

- The compression line, $\lambda$, the swelling line, $\kappa$, and the critical state line in $q-p$ plane are temperature independent.

- The normalization approach of normally consolidated triaxial stress-strain results by the preconsolidation pressures is valid at elevated temperatures.

- The preconsolidation pressure is temperature independent. However, the elastic zone at constant plastic strain is temperature dependent and its thermal evolution is a function of stress ratio $(\eta)$.

- The geometry of the Roscoe surface is temperature dependent. At elevated temperatures the Roscoe surface becomes steeper as the peak deviatoric stress increased and the ratio between the initial mean effective stress and the peak mean effective stress decreased.

- The flow rule is temperature dependent. The test results indicate that as the soil temperature increased the plastic strain increment ratio $\left(d \varepsilon_{\mathrm{v}}^{\mathrm{p}} / d \varepsilon_{\mathrm{s}}^{\mathrm{p}}\right)$ also increased.

- Thermal effects on shear strength, stiffness, and yielding behavior can be attributed to the thermally induced volume change and the thermally induced fabric changes.

\section{REFERENCES}

1) Abdel-Hadi, O. N. and Mitchell, J. K. (1981): Coupled heat and water flows around buried cables, J. Geotech. Engrg. Div., ASCE, 107(11), 1461-1487.

2) Abuel-Naga, H. M., Bergado, D. T. and Suttisak, S. (2006a): Innovative thermal technique for enhancing the performance of prefabricated vertical drain system, Geotextiles and Geomembranes, 24, 359-370.

3) Abuel-Naga, H. M., Bergado, D. T. and Bouazza, A. (2006b): Thermally induced volume change and excess pore water pressure of soft Bangkok clay, Engineering Geology, 89, 144-154.

4) Burghignoli, A., Desideri, A. and Miliziano, S. (2000): A laboratory study on the thermomechanical behaviour of clayey soils, Can. Geotech. J., 37, 764-780.

5) Campanella, R. G. and Mitchell, J. K. (1968): Influence of temperature variations on soil behavior, J. Geotech. Engrg. Div., ASCE, 94(3), 709-734.

6) Cekerevac, C. and Laloui, L. (2004): Experimental study of thermal effects on the mechanical behaviour of a clay, Int. J. Num. Anal. Meth. Geomech., 28, 209-228.

7) Cekerevac, C., Laloui, L. and Vulliet, L. (2005): A novel triaxial apparatus for thermo-mechanical testing of soils, Geotech. Test. J.,
ASTM, 28(2), 161-170.

8) Chapuis, R. P. and Aubertin, M. (2003): On the use of the KozenyCarman equation to predict the hydraulic conductivity of soils, Can. Geotech. J., 40, 616-628.

9) Crook, J. H. A. and Graham, J. (1976): Geotechnical properties of the Belfast estuarine deposits, Geotechnique, 26, 293-315.

10) Cui, Y. J., Sultan, N. and Delage, P. (2000): A thermo-mechanical model for saturated clays, Can. Geotech. J., 37, 607-620.

11) Delage, P., Sultan, N. and Cui, Y. J. (2000): On the thermal consolidation of Boom Clay, Can. Geotech. J., 37, 343-354.

12) Del. Olmo, C., Fioravante, V., Gera, F., Hueckel, T., Mayor, J.-C. and Pellegrini, R. (1996): Thermo-mechanical properties of deep argillaceous formations, Engrg. Geol., 41, 87-102.

13) Eriksson, L. G. (1989): Temperature effects on consolidation properties of sulphide clays, 12th ICSMFE, Rio de Janeiro, 2087-2090.

14) Gera, F., Hueckel, T. and Peano, A. (1996): Critical issues in modelling of the long-term hydro-thermal performance of natural clay barriers, Engrg. Geol., 41, 17-33.

15) Graham, J., Tanaka, N., Crilly, T. and Alfaro, M. (2001): Modified Cam-Clay modeling of temperature effects in clays, Can. Geotech. J., 38, 608-621.

16) Gray, H. (1936): Progress report on research on the consolidation of fine-grained soils, 1st ICSMFE, Cambridge, 138-141.

17) Grozic, J. L. H., Lunne, T. and Pande, S. (2003): An oedometer test study on the preconsolidation stress of glaciomarine clays, Can. Geotech. J., 40, 857-872.

18) Head, K. H. (1986): Manual of Soil Laboratory Testing, John Wiley \& Sons, Inc., New York, NY.

19) Hueckel, T. and Baldi, M. (1990): Thermoplastic of saturated clays: an experimental constitutive study. J. Geotech. Engrg., ASCE, 116(12), 1778-1796.

20) Kuntiwattanakul, P., Towhata, I., Ohishi, K. and Seko, I. (1995): Temperature effects on undrained shear characteristics of clay, Soils and Foundations, 35(1), 147-162.

21) Ladd, C. C. (1964): Stress-strain modulus of clay in undrained shear, J. Soil Mech. Found. Div., ASCE, 90(5), 103-132.

22) Laloui, L. (2001): Thermo-mechanical behavior of soils, Revue Française de Génie Civil., 5(6), 809-843.

23) Leroueil, S., Tavenas, F., Brucy, F., Rochelle, P. and Roy, M. (1979): Behavior of destructured natural clays, J. Geotech. Engrg., ASCE, 105(6), 759-778.

24) Lim, F. B. (2005): Undrained shear strength of soft Bangkok Clay at elevated temperatures, Master Thesis, Asian Institute of Technology, Thailand.

25) Moritz, L. (1995): Geotechnical properties of clay at elevated temperatures, Int. Sym. Compression and Consolidation of Clayey Soils, IS-Hiroshima, Japan, 267-272.

26) Ohtsubo, M., Egashira, K., Koumoto, T. and Bergado, D. T. (2000): Mineralogy and chemistry, and their correlation with the geotechnical index properties of Bangkok clay: Comparison with Ariake clay, Soils and Foundations, 40(1), 11-21.

27) Push, R. and Guven, N. (1990): Electron microscopic examination of hydrothermally treated Bentonite clay, Engrg. Geol., 28, 303-314.

28) Sivakumar, V., Doran, I. G. and Graham, J. (2002): Particle orientation and its influence on the mechanical behavior of isotropically consolidated reconstituted clay, Engrg. Geol., 66, 197-209.

29) Slegel, D. L. and Davis, L. R. (1977): Transient heat and mass transfer in soils in the vicinity of heated porous pipes, J. Heat Transfer, 99, 541-621.

30) Sultan, N., Delage, P. and Cui, Y. J. (2002): Temperature effects on the volume change behavior of Boom clay, Engrg. Geol., 64, 135-145.

31) Towhata, I., Kuntiwattanakul, P., Seko, I. and Ohishi, K. (1993): Volume change of clays induced by heating as observed in consolidation tests, Soils and Foundations, 33(4), 170-183.

32) Wood, D. M. (1990): Soil Behavior and Critical State Soil Mechanics, Cambridge University Press, Cambridge, England. 